\title{
Analysis of Annual Dissolved-Solids Loading from Selected Natural and Irrigated Catchments in the Upper Colorado River Basin, 1974-2003
}

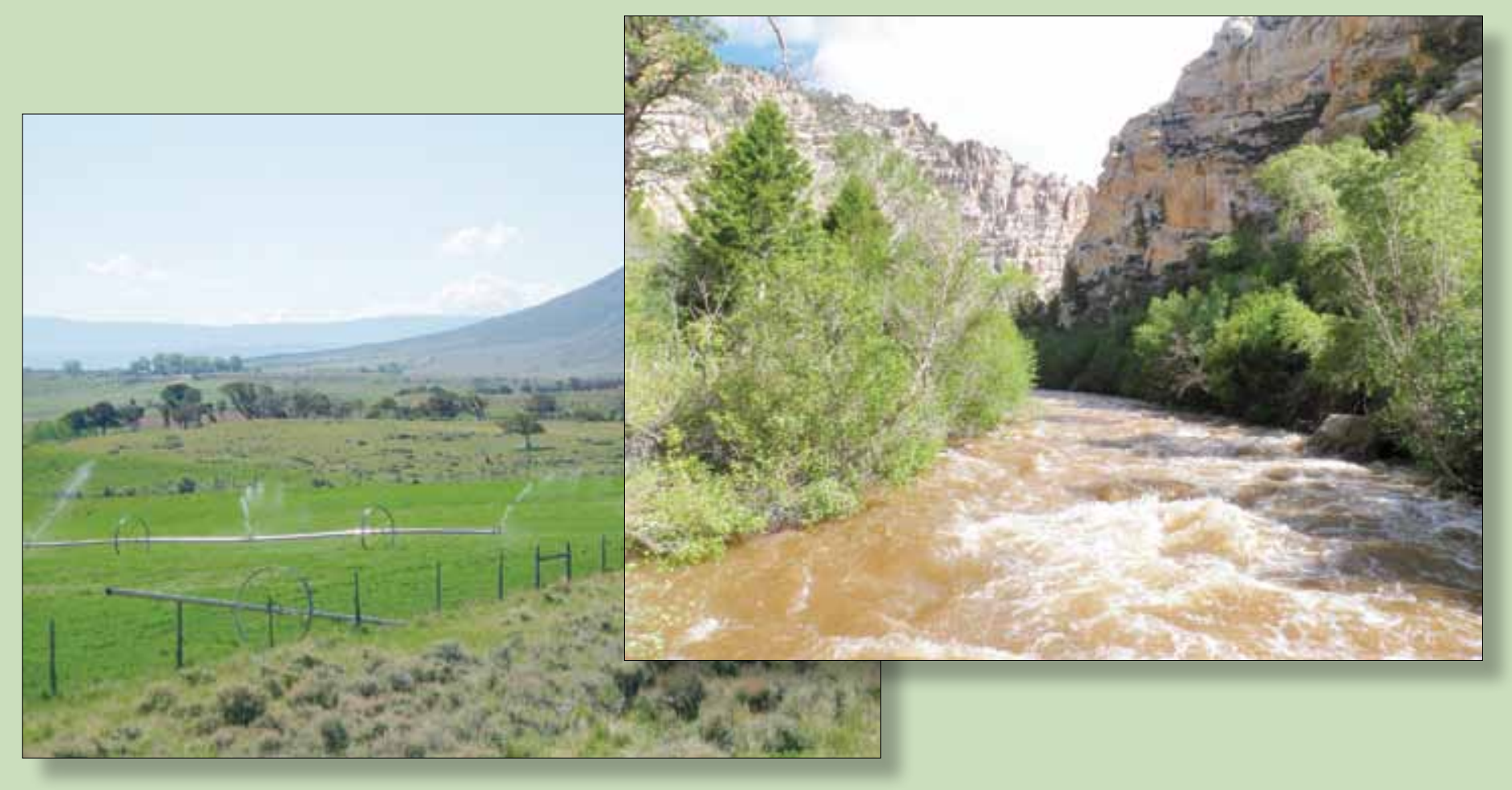

Prepared in cooperation with the U.S. Department of the Interior, Bureau of Reclamation

Scientific Investigations Report 2012-5090 
Cover: Photo on left: Irrigated agricultural lands near Antelope Wash, Uinta Mountains, Utah. Photo on right: Ashley Creek near Vernal, Utah, looking upstream. 


\section{Analysis of Annual Dissolved-Solids Loading from Selected Natural and Irrigated Catchments in the Upper Colorado River Basin, 1974-2003}

By Terry A. Kenney, Steven J. Gerner, and Susan G. Buto

Prepared in cooperation with the U.S. Department of the Interior,

Bureau of Reclamation

Scientific Investigations Report 2012-5090 


\title{
U.S. Department of the Interior \\ KEN SALAZAR, Secretary \\ U.S. Geological Survey \\ Marcia K. McNutt, Director
}

\author{
U.S. Geological Survey, Reston, Virginia: 2012
}

For more information on the USGS - the Federal source for science about the Earth, its natural and living resources, natural hazards, and the environment, visit http://www.usgs.gov or call 1-888-ASK-USGS.

For an overview of USGS information products, including maps, imagery, and publications, visit http://www.usgs.gov/pubprod

To order this and other USGS information products, visit http://store.usgs.gov

Any use of trade, product, or firm names is for descriptive purposes only and does not imply endorsement by the U.S. Government.

Although this report is in the public domain, permission must be secured from the individual copyright owners to reproduce any copyrighted materials contained within this report.

Suggested citation:

Kenney, T.A., Gerner, S.J., and Buto, S.G., 2012, Analysis of annual dissolved-solids loading from selected natural and irrigated catchments in the Upper Colorado River Basin, 1974-2003: U.S. Geological Survey Scientific Investigations Report 2012-5090, 20 p. 


\section{Contents}

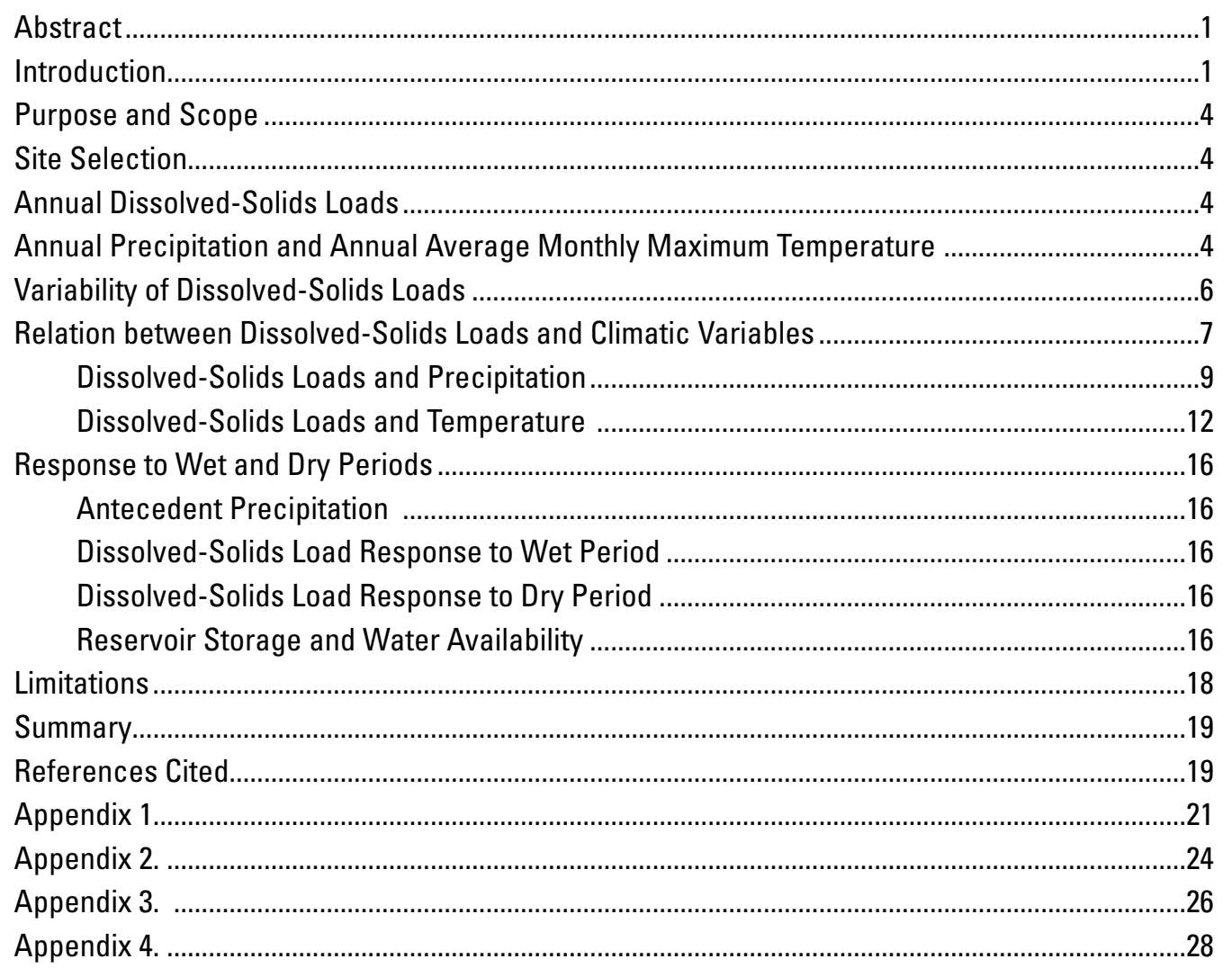




\section{Figures}

1. Map showing upper Colorado River Basin study area

2. Diagram of conceptual model illustrating the processes by which dissolved solids are generated and transported to streams in the Upper Colorado River Basin

3. Map showing selected natural and agricultural catchments in the Upper Colorado River Basin.

4. Graph showing average normalized annual dissolved-solids loads for selected natural and irrigated catchments in the Upper Colorado River Basin. 6

5. Graph showing annual change in average normalized dissolved-solids loads for selected natural and irrigated catchments in the Upper Colorado River Basin

6. Bar chart showing correlation coefficients computed between normalized annual dissolved-solids loads and normalized annual precipitation for natural catchments in the Upper Colorado River Basin

7. Bar chart showing correlation coefficients computed between normalized annual dissolved-solids loads and normalized annual precipitation for irrigated catchments in the Upper Colorado River Basin

8. Graph showing normalized precipitation and temperature for selected irrigated and natural catchments in the Upper Colorado River Basin

9. Bar chart showing correlation coefficients computed between normalized annual dissolved-solids loads and normalized annual monthly (April through October) average maximum temperature for natural catchments in the Upper Colorado River Basin.

10. Bar chart showing correlation coefficients computed between normalized annual dissolved solids-loads and normalized annual monthly (April through October) average maximum temperature for irrigated catchments in the Upper Colorado River Basin 


\section{Tables}

1. Variability of normalized annual dissolved-solids loads in selected catchments of the Upper Colorado River Basin

2. Correlation coefficients computed between normalized annual dissolvedsolids loads and normalized annual precipitation for selected catchments in the Upper Colorado River Basin ...

3. Correlation coefficients computed between normalized annual dissolvedsolids loads and normalized annual monthly (April through October) average maximum temperature for selected catchments in the Upper Colorado River Basin

4. Maximum normalized dissolved-solids loads during the wet period from 1982 through 1987 for selected catchments in the Upper Colorado

River Basin 


\section{Conversion Factors}

Inch/Pound to SI

\begin{tabular}{|c|c|c|}
\hline Multiply & By & To obtain \\
\hline \multicolumn{3}{|c|}{ Length } \\
\hline inch (in) & 2.54 & centimeter $(\mathrm{cm})$ \\
\hline \multicolumn{3}{|c|}{ Area } \\
\hline acre & 0.4047 & hectare (ha) \\
\hline square mile $\left(\mathrm{mi}^{2}\right)$ & 2.590 & square kilometer $\left(\mathrm{km}^{2}\right)$ \\
\hline \multicolumn{3}{|c|}{ Volume } \\
\hline acre-foot (acre-ft) & 1,233 & cubic meter $\left(\mathrm{m}^{3}\right)$ \\
\hline \multicolumn{3}{|c|}{ Mass } \\
\hline ton & 0.9072 & metric ton \\
\hline
\end{tabular}

Temperature in degrees Celsius $\left({ }^{\circ} \mathrm{C}\right)$ may be converted to degrees Fahrenheit $\left({ }^{\circ} \mathrm{F}\right)$ as follows:

${ }^{\circ} \mathrm{F}=\left(1.8 \times{ }^{\circ} \mathrm{C}\right)+32$

Temperature in degrees Fahrenheit $\left({ }^{\circ} \mathrm{F}\right)$ may be converted to degrees Celsius $\left({ }^{\circ} \mathrm{C}\right)$ as follows:

${ }^{\circ} \mathrm{C}=\left({ }^{\circ} \mathrm{F}-32\right) / 1.8$

\section{Abbreviations}

AAOTMax annual average monthly (April through October) maximum temperature

ENSO El Niño-Southern Oscillation

IOR interquartile range

PDO Pacific Decadal Oscillation

PRISM Parameter-elevation Regressions on Independent Slopes Model

Reclamation Bureau of Reclamation

SPARROW Spatially Referenced Regressions on Watershed Attributes

UCRB Upper Colorado River Basin

USGS U.S. Geological Survey 


\title{
Analysis of Annual Dissolved-Solids Loading from Selected Natural and Irrigated Catchments in the Upper Colorado River Basin, 1974-2003
}

\author{
By Terry A. Kenney, Steven J. Gerner, and Susan G. Buto
}

\section{Abstract}

Dissolved-solids loading from 17 natural catchments and 14 irrigated catchments in the Upper Colorado River Basin was examined for the period from 1974 through 2003. In general, dissolved-solids loading increased and decreased concurrently in natural and irrigated catchments but at different magnitudes. Annually, the magnitude of loading in natural catchments changed about 10 percent more, on average, than in irrigated catchments. Measures of variability, or spread, indicate that natural catchments had 35 percent greater annual variability in loading than irrigated catchments. Precipitation and dissolved-solids loads were positively correlated in natural catchments, and a weak positive correlation was determined for irrigated catchments. A weak negative correlation between temperature and dissolved-solids load was determined for both natural and irrigated catchments. In irrigated catchments, the dissolved-solids load response to an above-average precipitation period from 1982 through 1987 generally lagged behind that in the natural catchments. On average, irrigated catchments with reservoir storage had the largest normalized maximum annual loads during the wet period.

\section{Introduction}

The 108,000 square mile $\left(\mathrm{mi}^{2}\right)$ drainage area of the Upper Colorado River Basin (UCRB) includes portions of Wyoming, Colorado, Utah, New Mexico, and Arizona (fig. 1). For this report, the UCRB is defined as the contributing drainage area upstream of U.S. Geological Survey (USGS) streamflow-gaging station 09380000, Colorado River at Lees Ferry, Arizona. The landscape in the UCRB is varied and includes alpine forests, arid badlands, and slickrock canyonlands. The major rivers of the UCRB are the Colorado, Green, and San Juan, and the headwaters of these rivers generally are located within highly-deformed crustal blocks of the Central Rocky Mountains. The geology of these headwater areas stands in distinct contrast to the undeformed rocks of the Colorado Plateau, which generally compose the lower one-third of the UCRB.
During the past 30 years, the UCRB, on average, annually discharged about 7 million tons of dissolved solids, as computed at Lees Ferry, Arizona (Anning and others, 2007). It is estimated that between 40 and 45 percent of the dissolvedsolids load at Lees Ferry, Arizona, is attributable to irrigated agriculture in the UCRB (Iorns and others, 1965; Kenney and others, 2009).

Dissolved-solids concentrations and loads in streams in the UCRB have been measured or estimated at numerous locations for various surface-water-quality assessments during the past century. These and other investigations have developed a solid conceptual understanding of the sources, transport mechanisms, and the ultimate fate of dissolved solids in the UCRB (fig. 2). The major sources of dissolved solids in UCRB streams are categorized as natural, which includes geologic formations and saline springs, or anthropogenic, which includes irrigated agricultural lands (Iorns and others, 1965; Kenney and others, 2009; U.S. Department of the Interior, 2009).

The conceptual understanding of dissolved-solids loading to streams in the UCRB has been applied to the framework of the USGS Spatially Referenced Regressions on Watershed Attributes (SPARROW) surface-water-quality model (Anning and others, 2007; Kenney and others, 2009) and other models to obtain estimates of dissolved-solids loads at unmonitored locations as well as to provide a more comprehensive basinwide perception of salinity in the UCRB. These models have verified the conceptual understanding of the sources of dissolved solids in the basin and have enhanced the understanding of a variety of the transport mechanisms. For example, precipitation and evapotranspiration were among seven statistically significant landscape transport characteristics in the UCRB dissolved-solids SPARROW model (Kenney and others, 2009). Interestingly, precipitation and evapotranspiration are the only time-specific independent parameters in the UCRB SPARROW model that vary year-to-year (Kenney and others, 2009; Kenney and Buto, 2012). Estimated SPARROW model coefficients for precipitation and evapotranspiration show that increases in either parameter lead to an increase in dissolved-solids load (Kenney and others, 2009). 


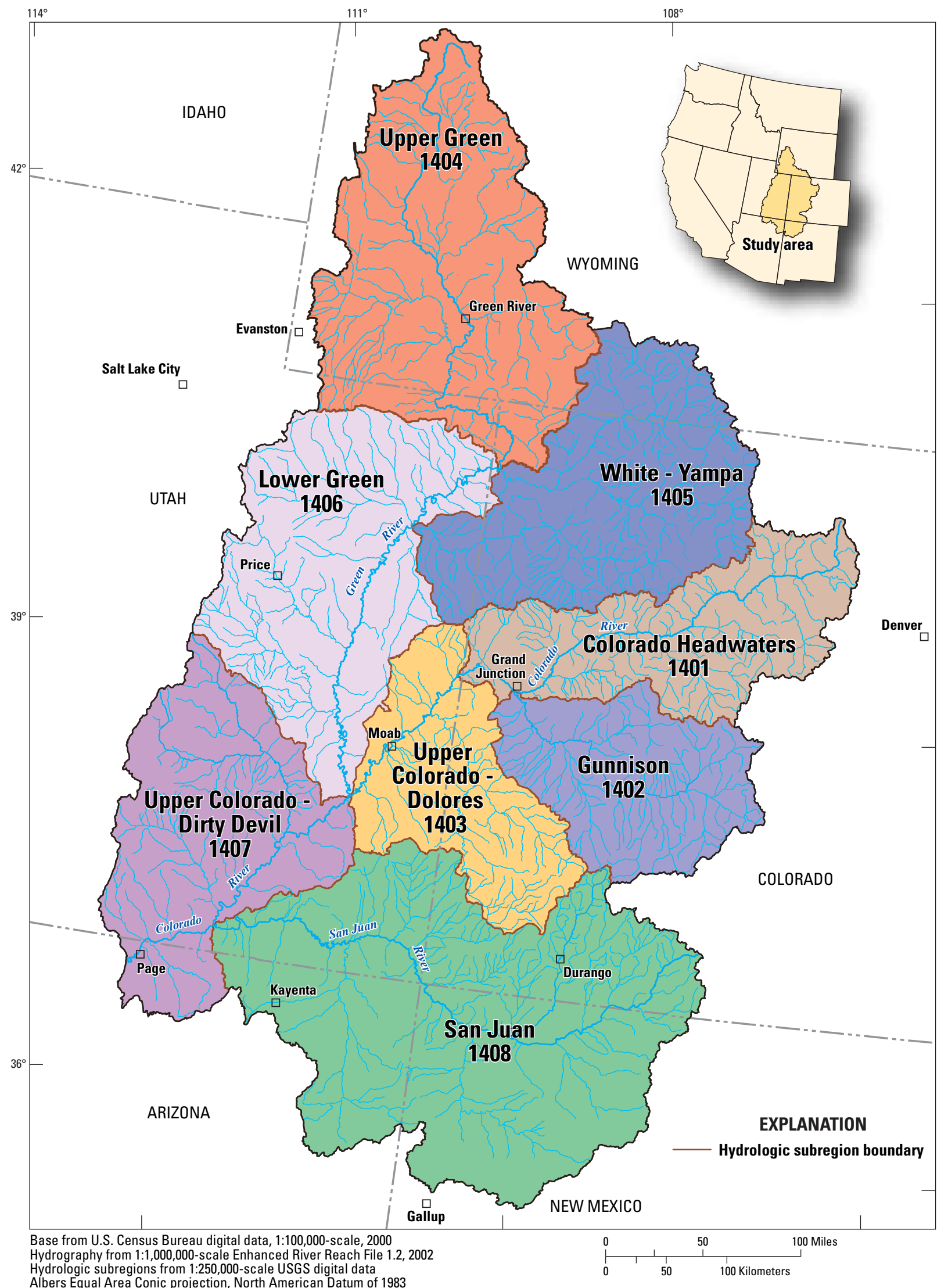

Figure 1. Upper Colorado River Basin study area. 


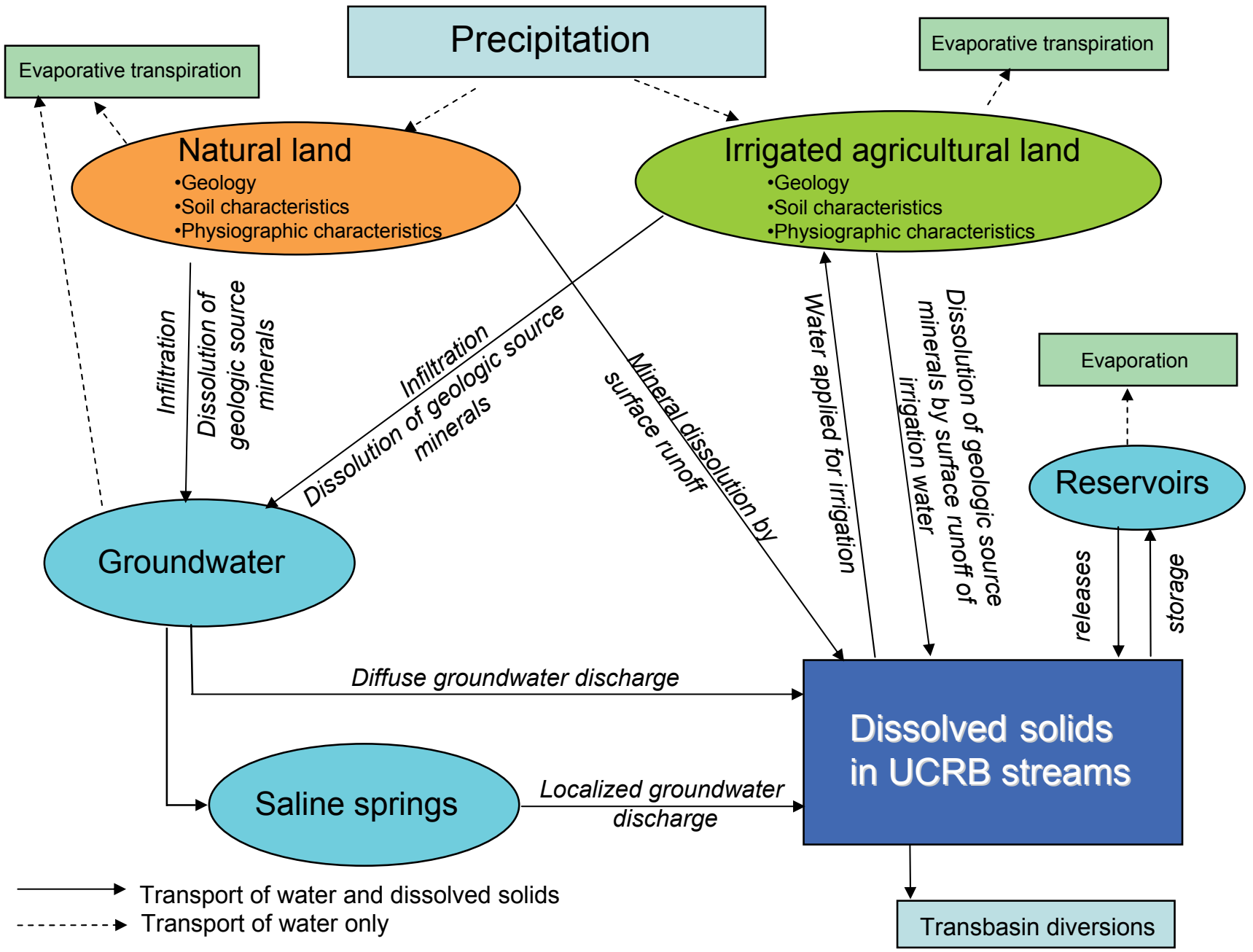

Figure 2. Conceptual model illustrating the processes by which dissolved solids are generated and transported to streams in the Upper Colorado River Basin (UCRB; modified from Kenney and others, 2009).

When constructing the UCRB SPARROW model, conceptually, the effects of precipitation and evapotranspiration as transport mechanisms were assumed to be associated only with the natural, geologic sources of dissolved solids and not the anthropogenic, irrigated-land sources. This assumption implies that dissolved solids are derived from agricultural lands in the UCRB as a result of the application of irrigation water, soil disturbance, and, to a lesser degree, the application of soluble fertilizers (Kenney and others, 2009). Thus, for irrigated lands, precipitation and evapotranspiration were not designated as landscape transport characteristics in the effort to model sources of dissolved solids from irrigated lands. Elevation was the only landscape transport characteristic assigned to sources from irrigated lands because it represents a distinguishing characteristic affecting the amount of water used for irrigated crops in different locations within the UCRB (Kenney and others, 2009).
The construct of the UCRB SPARROW model and other dissolved-solids modeling exercises undertaken in the UCRB, incorporates the general assumption that loads associated with agricultural lands vary minimally year-to-year. This report, which was prepared in cooperation with the U.S. Department of the Interior's Bureau of Reclamation (Reclamation), tests this assumption by examining the variability in salt loading from catchments dominated by natural sources compared to catchments dominated by anthropogenic or irrigated agricultural sources. It also examines the correlation between precipitation and dissolved-solids load and between temperature and dissolved-solids load for the two catchment types. In this report, "year" refers to "water year,"- the period spanning October of the previous year through September of the current year. Annual dissolved-solids loads, annual precipitation, and annual temperature values were computed for every water year where data were available. For example, the annual dissolvedsolids load for 1983 represents the computed load for the months October 1982 through September 1983. 


\section{Purpose and Scope}

The purpose of this report is to present an understanding of how dissolved-solids loading in catchments dominated by natural sources differs from loading in catchments dominated by irrigated agricultural lands and how loads from irrigated and natural catchments relate to precipitation and temperature. It also presents an examination of the variability of dissolved-solids loads computed for a selection of catchments that have monitoring stations in the UCRB. Catchments were classified by their dominant dissolved-solids load source: natural geologic or irrigated agricultural lands. Expanding on this assessment of variability, climatic drivers, specifically precipitation and temperature, and their relation to loading from both source types also are examined. Furthermore, currently, it is not clear what effect multi-year wet or dry periods have on dissolved-solids loads discharged from natural and irrigated catchments. A qualitative discussion of the dissolvedsolids loading response to wet and dry periods between 1974 and 2003, from both natural and irrigated catchments in the UCRB, is included. Limitations and uncertainties in the analysis, including how the results should be interpreted, are outlined explicitly.

\section{Site Selection}

Catchments chosen for this study (fig. 3; appendix 1) were a subset of the calibration reaches with outlet water-quality monitoring stations that had been used in the calibration of both the southwestern dissolved-solids SPARROW model presented in Anning and others (2007) and the UCRB dissolvedsolids SPARROW model presented in Kenney and others (2009). Most of the catchments chosen for the study were incremental and did not represent entire upstream watersheds because they were bound upstream by water-quality monitoring stations, or water-quality monitoring stations and headwaters. To define catchments that met specified criteria for this analysis, dissolved-solids loads associated with upstream monitoring sites were subtracted from the loads associated with the monitoring site at the catchment outlet using available data. A total of 31 catchments met criteria for two groups: (1) natural catchments, where 10 percent or less of the dissolved solids originating and discharging from the catchment were derived from irrigated lands, and (2) agricultural catchments, where 70 percent or more of the dissolved solids originating and discharging from the catchment were derived from irrigated lands (fig. 3). The percentage of dissolved solids associated with irrigated lands discharged from the catchments was determined from the results of the UCRB dissolvedsolids SPARROW model (Kenney and others, 2009), which represented conditions during 1991. Because of limited data for irrigated lands throughout the UCRB, the dataset used in Kenney and others (2009), which was provided by Reclamation, "Potentially irrigated lands in Colorado, New Mexico, Utah, and Wyoming" (David Eckhart, Bureau of Reclamation, written commun., September 28, 2006), and the results of Kenney and others (2009) concerning the proportional amount of dissolved-solids loading from irrigated lands, were assumed to be representative of the catchments in most years. To simplify the analysis, catchments in which a substantial portion of the salt load was associated with natural point sources, such as large saline springs, were not included. Because of limited long-term dissolved-solids monitoring data in the UCRB for the years 1974-2003, the periods of record of computed annual dissolved-solids loads for the selected catchments ranged from 10 to 26 years and averaged 16.6 years.

\section{Annual Dissolved-Solids Loads}

Annual dissolved-solids loads from all monitoring stations bounding catchments meeting the criteria described previously were taken from Anning and others (2007). Annual dissolvedsolids loads for each catchment were calculated by subtracting loads associated with upstream monitoring stations from computed loads at the catchment outlet monitoring station. For this reason, dissolved-solids loads provided in Anning and others (2007) for most monitoring stations located at selected catchment outlets are larger than those assigned to many of the catchments (appendix 2). Annual dissolved-solids loads were mean-normalized by dividing each annual load by the average annual load of the respective catchment. Normalizing ensures that differences in the magnitudes of the loads, as well as differences in catchment size, do not influence the analysis, and it allows for equal comparisons among all catchments. All loads discussed in this report, unless stated otherwise, were mean-normalized.

\section{Annual Precipitation and Annual Average Monthly Maximum Temperature}

The current conceptual understanding of dissolved-solids load transport in the UCRB indicates that precipitation and temperature explain much of the variability in loading in UCRB streams (Anning and others, 2007; Kenney and others, 2009). Estimates of monthly precipitation and air temperature from the 4-kilometer resolution Parameter-elevation Regressions on Independent Slopes Model (PRISM) product (PRISM Group, 2007) were used to compute annual (water year) precipitation (appendix 3) and annual average monthly (April through October) maximum temperature (AAOTMax) for each defined catchment (appendix 4). Catchment annual precipitation and AAOTMax were mean-normalized by dividing each annual value by the average annual value of the respective catchment. This was done in order to make equal comparisons among catchments located at different elevations because higher elevations generally have more precipitation and cooler temperatures than lower elevations. 


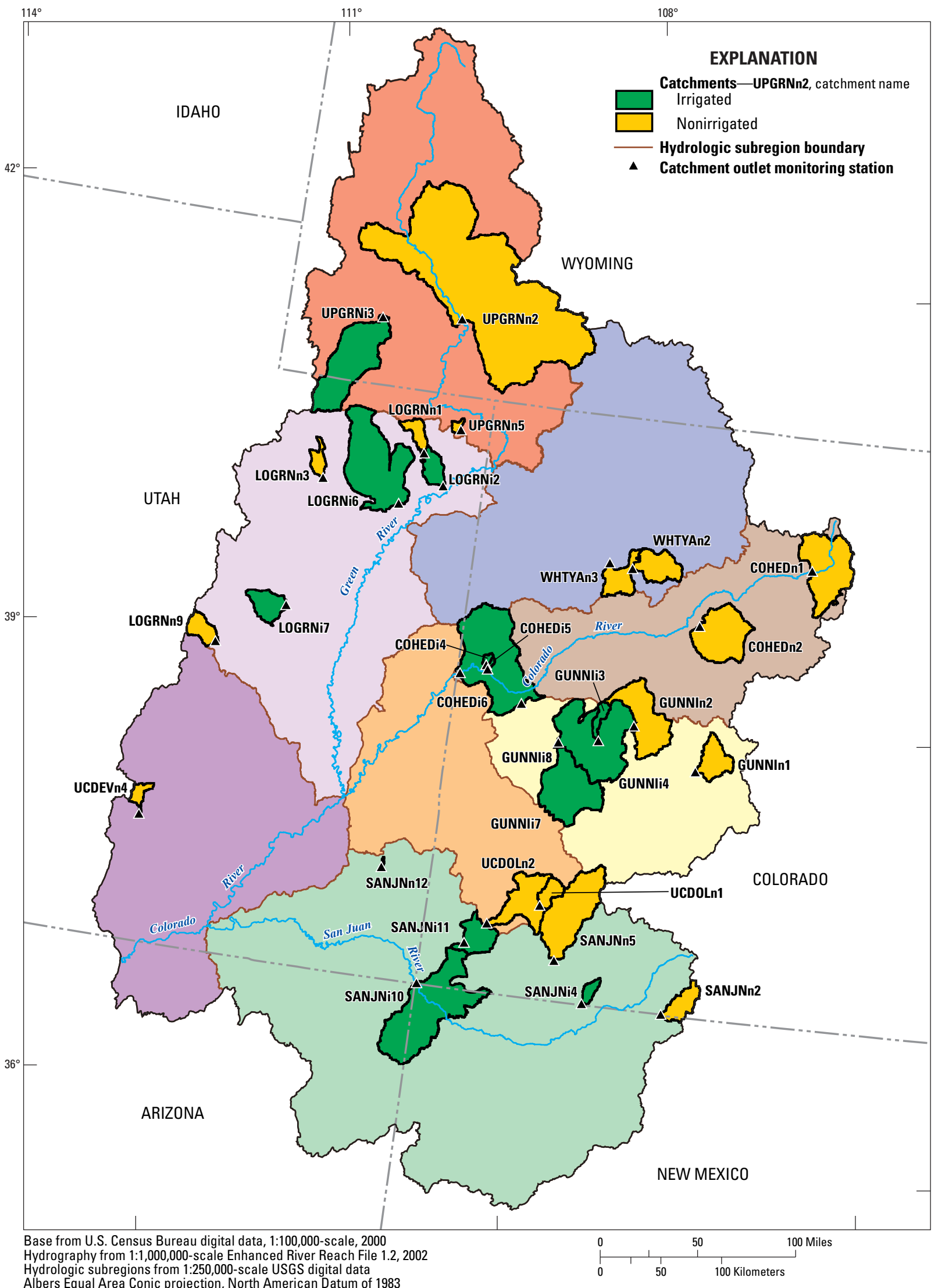

Figure 3. Selected natural and agricultural catchments in the Upper Colorado River Basin. 


\section{Variability of Dissolved-Solids Loads}

The average annual dissolved-solids load for natural and irrigated catchments was computed for each year from 1974 through 2003 (fig. 4). The time series shows a similar pattern of change in loading for both the natural and irrigated catchments in this study. The two catchment types show concurrent increases and decreases in dissolved-solids loads for all years but 1987, 1999, 2001, and 2003. However, the magnitude of change is generally lower for irrigated catchments.

To illustrate how the averaged annual dissolved-solids loads changed from one year to the next, the annual change, as a percent, in the average load (fig. 4) was computed by using the equation:

$$
\delta_{\text {percent }}=\left[\frac{\left(\bar{L}_{i+1}-\bar{L}_{i}\right)}{\bar{L}_{i}}\right] 100
$$

where

$$
\begin{gathered}
\delta_{\text {percent }} \quad \begin{array}{c}
\text { is the annual change in the average } \\
\text { normalized dissolved-solids load from year } \\
\text { i to year i+1 (in percent), }
\end{array} \\
\bar{L}_{i} \quad \begin{array}{c}
\text { is the average normalized annual dissolved- } \\
\text { solids load of year i (dimensionless), and }
\end{array} \\
\bar{L}_{i+1} \quad \begin{array}{c}
\text { is the average normalized annual dissolved- } \\
\text { solids load of year i+1 (dimensionless). }
\end{array}
\end{gathered}
$$

The annual change in average dissolved-solids loads for the natural and irrigated catchments is shown in figure 5.

Loading associated with both natural and irrigated catchments varied annually; however, the magnitude of change from one year to the next for irrigated catchments generally was lower than for the natural catchments. The average of the absolute values of the percent of annual change in loading for natural catchments was 29 percent, compared to 19 percent for irrigated catchments. The maximum of the absolute values of the percent of annual change in loading in natural catchments was

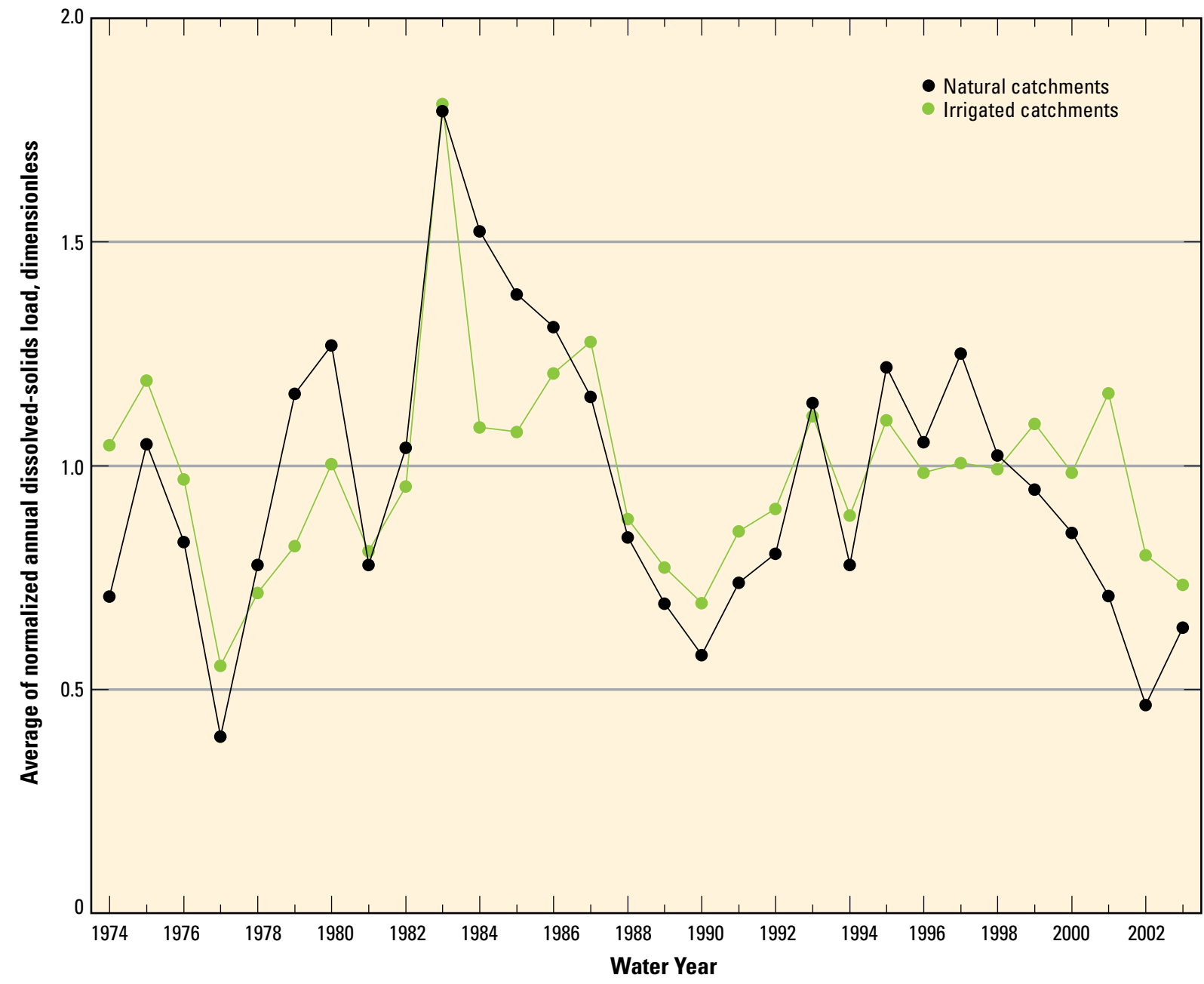

Figure 4. Average normalized annual dissolved-solids loads for selected natural and irrigated catchments in the Upper Colorado River Basin. 
97 percent and was 90 percent for irrigated catchments; the minima were 5 percent and less than 1 percent for natural and irrigated catchments, respectively.

When evaluating variability, statistical metrics that provide a measurement of the population spread, such as standard deviation and interquartile range (IQR) are often used. The standard deviation is computed by using the squares of the deviations of data from the mean, so that outliers influence the magnitude (Helsel and Hirsch, 1992). The IQR is the range of the central 50 percent of the population, which is computed by subtracting the $25^{\text {th }}$ percentile from the $75^{\text {th }}$ percentile. The IQR is not influenced by outliers because the highest and lowest 25 percent of the population are not considered. The IQR is the most commonly used outlier-resistant measure of spread (Helsel and Hirsch, 1992). The outlier-resistant properties of the IQR were ideal for this analysis because of the small sample sizes available for the individual catchments. The IQR was computed for the normalized annual dissolved-solids load of each catchment for its available period of record (table 1). The average IQR for natural catchments was 0.51 , and the IQR for irrigated catchments was 0.38 . The sample sizes for the catchments ranged from 10 to 26 years for dissolved-solids loads and averaged 16.6 years. The variability of dissolvedsolids loads in natural catchments, as determined by the average IQR, was about 35 percent greater than the variability in irrigated catchments. Three of the five irrigated catchments with the highest IQRs also had the greatest amounts of incatchment storage. This could indicate that greater variability in normalized annual dissolved-solids loads is associated with in-catchment reservoir storage in irrigated catchments. The natural catchments did not appear to differ in variability relative to in-catchment reservoir storage.

\section{Relation between Dissolved-Solids Loads and Climatic Variables}

Dissolved-solids loads at all monitoring sites, in both natural and irrigated catchments in the UCRB showed annual variability. Climate, specifically precipitation and temperature, appears to be the major causal mechanism of this variability (Anning and others, 2007; Kenney and others, 2009). The presence or absence of upstream reservoirs also could play a role in the variability of dissolved-solids loading in the UCRB.

Correlation analyses between dissolved-solids loads and precipitation, and between dissolved-solids loads and temperature, were done for each of the 31 catchments studied. Correlation provides a measure of observed co-variation, but it is not evidence of a causal relation between two variables. Attribution of a causal relation comes from understanding processes involving the variables (Helsel and Hirsch, 1992). The correlation analyses for this study evaluated how load varied with the climatic variables, precipitation, and temperature. For example, if precipitation increases, then how does load respond? These analyses, by means of determined correlation coefficients, also provide a measure of the strength of the relation between the variables.

Most of the catchment sample populations of annual dissolved-solids loads were small (less than 20), skewed, and not distributed normally (appendix 1). Further, the relations between precipitation and load, and temperature and load, do not appear to be linear. Because of these characteristics, the nonparametric Kendall's rank correlation test was selected to measure the strength of the assumed monotonic relation between dissolved-solids loads and precipitation, and between

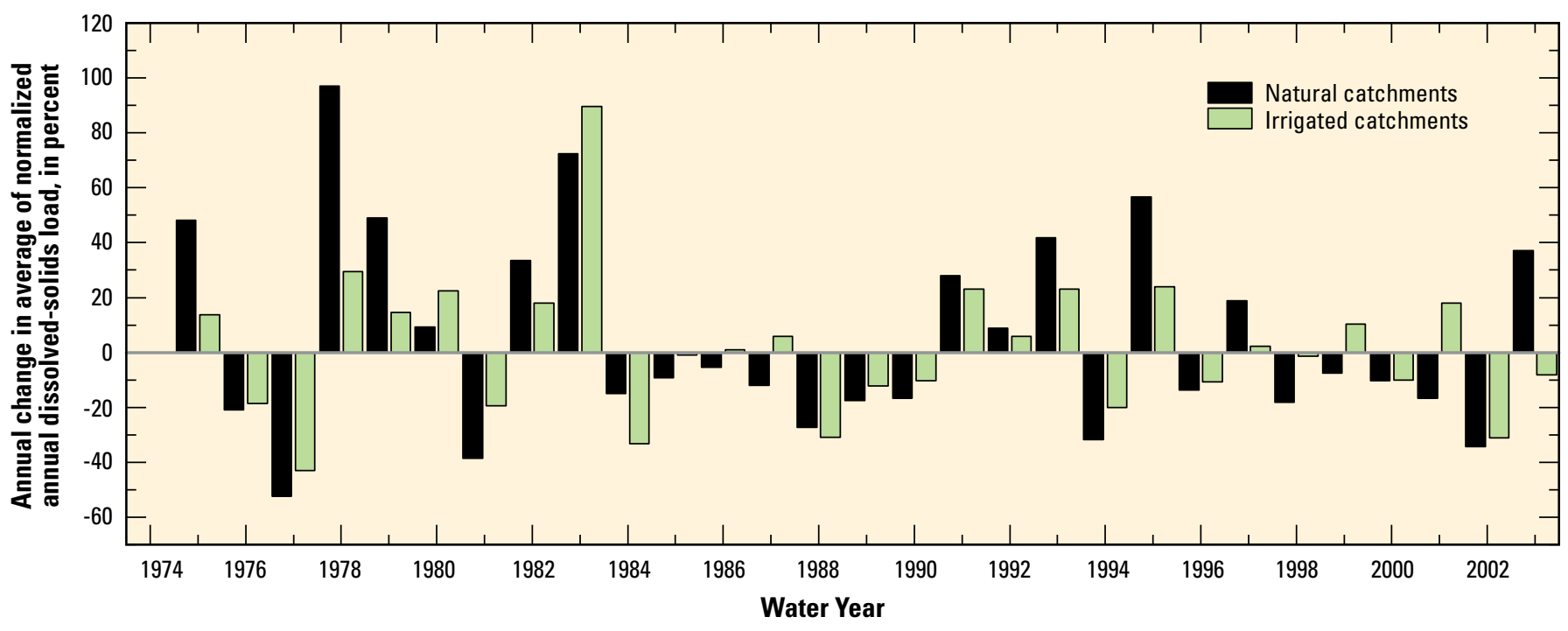

Figure 5. Annual change in average normalized dissolved-solids loads for selected natural and irrigated catchments in the Upper Colorado River Basin. 
Table 1. Variability of normalized annual dissolved-solids loads for selected catchments in the Upper Colorado River Basin. [na, not applicable]

\begin{tabular}{|c|c|c|c|c|}
\hline Catchment name & $\begin{array}{l}\text { Interquartile range of } \\
\text { normalized annual } \\
\text { dissolved-solids loads }\end{array}$ & $\begin{array}{l}\text { 'Percentage of dissolved- } \\
\text { solids load associated with } \\
\text { irrigated lands }\end{array}$ & $\begin{array}{l}\text { Storage within catchment, } \\
\text { in acre-feet }\end{array}$ & $\begin{array}{l}\text { Storage upstream of } \\
\text { catchment, in acre-feet }\end{array}$ \\
\hline \multicolumn{5}{|c|}{ Natural catchments } \\
\hline WHTYA2n & 0.18 & 0 & 0 & 0 \\
\hline UPGRN2n & 0.29 & 8 & 0 & 392,500 \\
\hline LOGRN03n & 0.39 & 2 & 0 & 0 \\
\hline GUNNI1n & 0.43 & 1 & 0 & 106,200 \\
\hline LOGRN01n & 0.45 & 0 & 0 & 0 \\
\hline SANJN02n & 0.47 & 8 & 0 & 0 \\
\hline COHED1n & 0.51 & 7 & 574,750 & 0 \\
\hline UCDEV4n & 0.70 & 0 & 0 & 0 \\
\hline UPGRN5n & 0.70 & 0 & 0 & 0 \\
\hline WHTYA3n & 0.81 & 6 & 7,660 & 0 \\
\hline SANJN12n & 1.11 & 0 & 0 & 0 \\
\hline Average & 0.51 & 3 & na & na \\
\hline Minimum & 0.15 & 0 & na & na \\
\hline Maximum & 1.11 & 9 & na & na \\
\hline $\begin{array}{l}\text { Average of catchments without } \\
\text { in-catchment storage }\end{array}$ & 0.50 & 2 & na & na \\
\hline $\begin{array}{l}\text { Average of catchments with } \\
\text { in-catchment storage }\end{array}$ & 0.53 & 5 & na & na \\
\hline GUNNI4i & 0.28 & 98 & 23,400 & $1,097,000$ \\
\hline GUNNI7i & 0.28 & 100 & 0 & 0 \\
\hline LOGRN07i & 0.30 & 93 & 0 & 0 \\
\hline SANJN11i & 0.30 & 98 & 0 & 0 \\
\hline SANJN04i & 0.33 & 97 & 0 & 0 \\
\hline LOGRN2i & 0.45 & 94 & 38,170 & 0 \\
\hline UPGRN3i & 0.50 & 81 & 46,470 & 0 \\
\hline LOGRN06i & 0.61 & 90 & 29,900 & 0 \\
\hline SANJN10i & 0.78 & 77 & 0 & 0 \\
\hline GUNNI3i & 0.93 & 72 & 0 & 0 \\
\hline Average & 0.38 & 92 & na & na \\
\hline Minimum & 0.07 & 72 & na & na \\
\hline Maximum & 0.93 & 100 & na & na \\
\hline $\begin{array}{l}\text { Average of catchments without } \\
\text { in-catchment storage }\end{array}$ & 0.37 & 93 & na & na \\
\hline $\begin{array}{l}\text { Average of catchments with } \\
\text { in-catchment storage }\end{array}$ & 0.40 & 89 & na & na \\
\hline
\end{tabular}

${ }^{1}$ From Kenney and others, 2009. 
dissolved-solids loads and temperature. Kendall's correlation coefficient, tau, can range from +1 to -1 . The strength of the correlation depends on the closeness of the coefficient to either +1 or -1 . Positive values indicate that as one variable increases, the second variable increases; a negative coefficient indicates that as one variable increases, the other decreases; and a zero value indicates no correlation between variables. In general, a strong positive correlation is indicated with tau values of 0.7 and higher, and similarly, a strong negative correlation is indicated with tau values of -0.7 or lower.

\section{Dissolved-Solids Loads and Precipitation}

Conceptually, a causal relation exists between precipitation and dissolved-solids load because an increase in precipitation increases the capacity to dissolve and transport solids from sources to streams. Kendall's tau was computed for each catchment on pairs of dissolved-solids load and precipitation, as well as for all pairs from the two catchment types (table
2, figs. 6 and 7). For the 17 natural catchments, tau indicated 15 positive correlations that were significant at the $p<0.05$ level, and Kendall's tau for all pairs of dissolved-solids load and corresponding catchment annual precipitation was 0.48 , which is significant at the $p<0.05$ level. A $p$-value less than 0.05 represents a statistically significant correlation. For the 14 irrigated catchments, 7 were found to have positive correlations that were significant at the $p<0.05$ level. When using all pairs of normalized dissolved-solids load and corresponding catchment annual precipitation, tau was 0.27 and indicated a weak positive correlation significant at the $p<0.05$ level.

The results of the correlation analyses provide verification of the conceptual understanding that higher precipitation generally leads to larger dissolved-solids loads in natural basins. For the correlation tests, only 2 of the 17 natural catchments, LOGRN9n and UPGRN2n, showed no significant correlation between load and precipitation. A weak positive correlation and a large $p$-value were determined for catchment LOGRN9n. For catchment UPGRN2n, the correlation

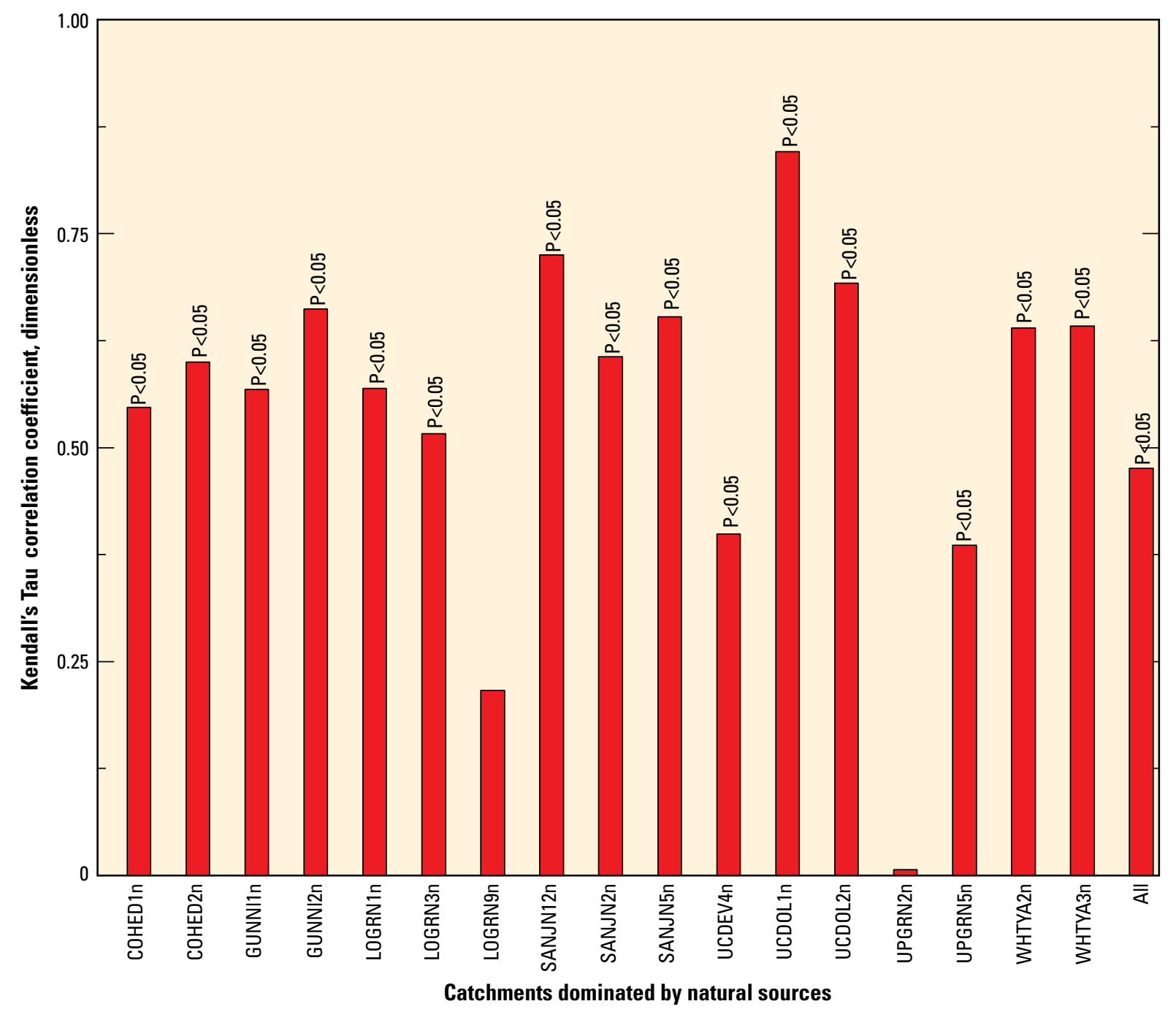

Figure 6. Correlation coefficients computed between normalized annual dissolved-solids loads and normalized annual precipitation for natural catchments in the Upper Colorado River Basin. A p-value less than 0.05 represents a statistically significant correlation. 
Table 2. Correlation coefficients computed between normalized annual dissolved-solids loads and normalized annual precipitation for selected catchments in the Upper Colorado River Basin.

[na, not applicable; <, less than]

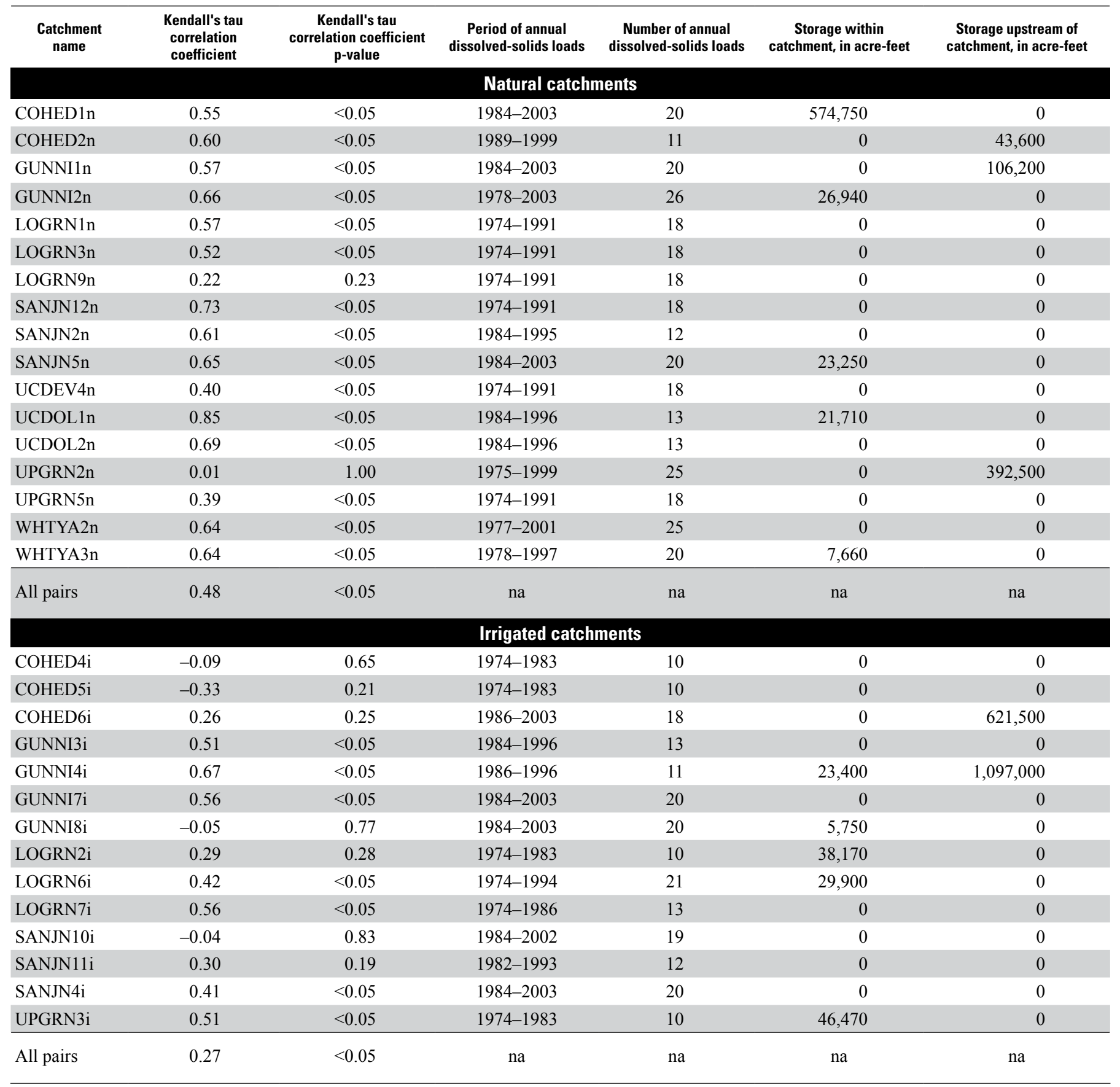

coefficient was near 0 , indicating no relation. This catchment covers a portion of the main stem Green River, defined by the outlet monitoring station 09217000, Green River near Green River, Wyoming. This catchment has the largest drainage area of all the selected catchments and also has the greatest amount of regulation upstream of the catchment. The analysis indicates that another process has a greater effect on dissolvedsolids loads in this catchment than precipitation.

Positive values of tau that were significant at the $p<0.05$ level were found in 7 of the 14 irrigated catchments, indicating that higher precipitation correlated to larger dissolved-solids loads. A weak positive correlation for all pairs of load and precipitation was determined as well. Qualitatively, it appears that years with higher precipitation usually generated larger dissolved-solids loads in irrigated basins. For irrigated catchments, tau for all pairs of loads and precipitation was 78 percent greater than tau for all pairs associated with the irrigated catchments. This indicates that precipitation was more strongly related to dissolved-solids loading in natural catchments than in irrigated ones. 


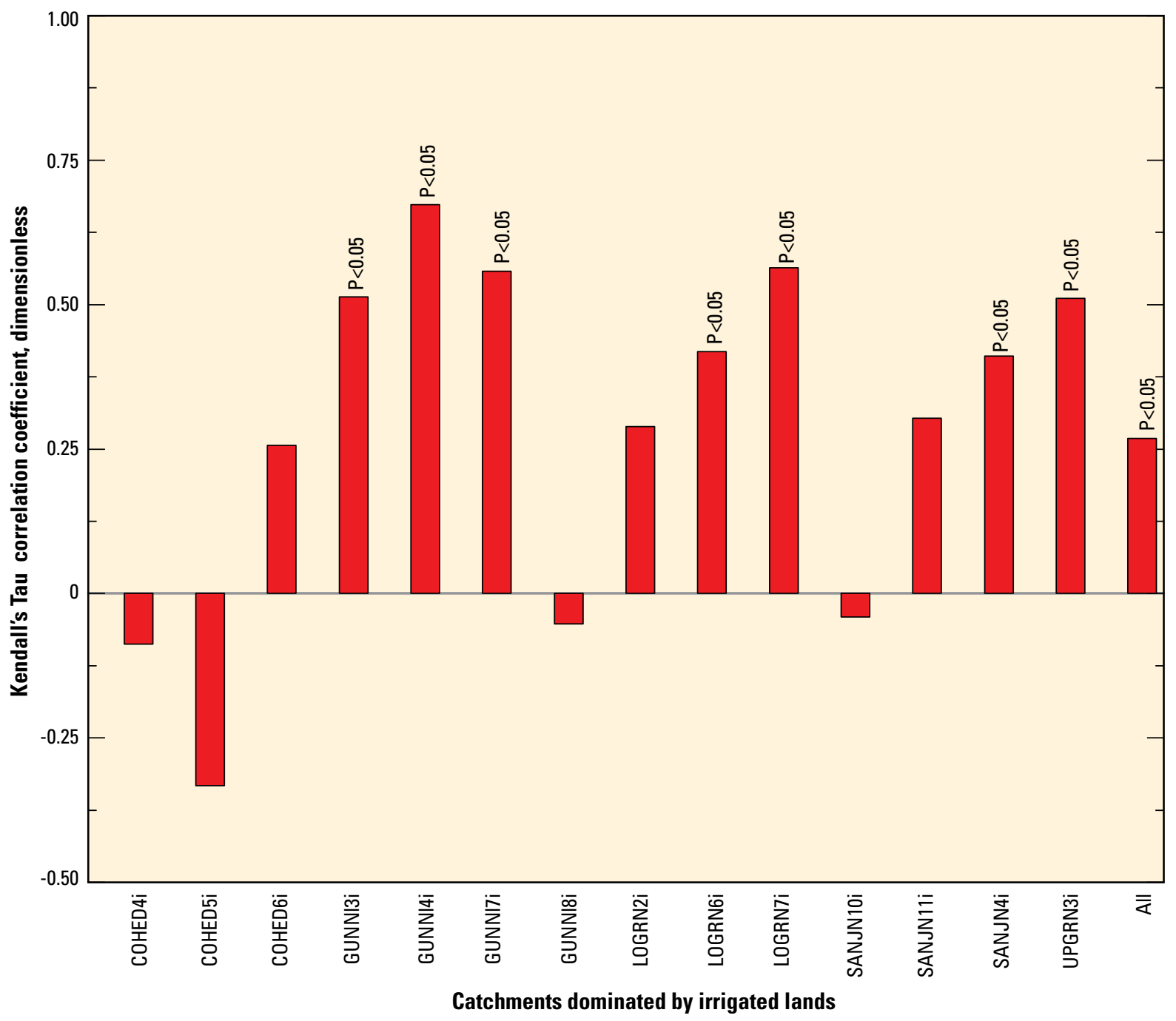

Figure 7. Correlation coefficients computed between normalized annual dissolved-solids loads and normalized annual precipitation for irrigated catchments in the Upper Colorado River Basin. A p-value less than 0.05 represent a statistically significant correlation. 


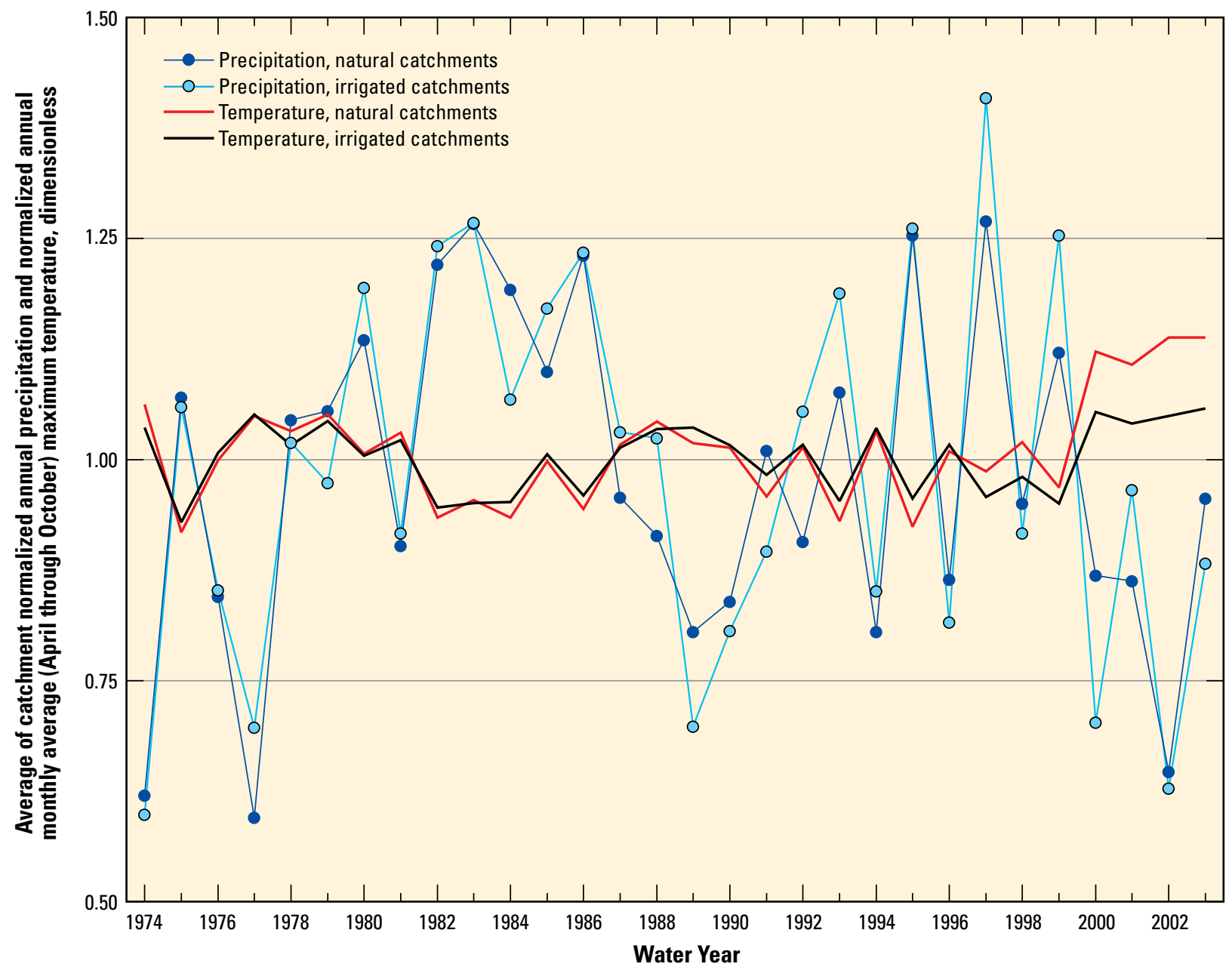

Figure 8. Normalized precipitation and temperature for selected irrigated and natural catchments in the Upper Colorado River Basin.

\section{Dissolved-Solids Loads and Temperature}

A causal relation between temperature and dissolved-solids load is not as clear in the literature as it is between precipitation and load. In the UCRB, cooler temperatures are related to wetter periods and vice versa (fig. 8), which indicates that a negative correlation exists between temperature and dissolvedsolids load; cooler temperatures correlate with larger loads. However, depending on the availability of irrigation water and irrigation practices, the relation between temperature and load from irrigated lands likely varies from one catchment to the next.
Kendall's tau values were computed for each catchment and AAOTMax as well as for all pairs of dissolved-solids load and AAOTMax for all natural and irrigated catchments (table 3, figs. 9 and 10). For the 17 natural catchments, Kendall's tau indicated 8 negative correlations that were significant at the $p<0.05$ level, and correlation coefficients computed for all pairs of normalized dissolved-solids load and corresponding AAOTMax indicated a weak negative correlation (tau equal to -0.27 ) at the $p<0.05$ level. For the 14 irrigated catchments, 4 were found to have negative correlations significant at the $p<0.05$ level by using Kendall's rank correlation. When using all pairs of dissolved-solids load and corresponding catchment AAOTMax, tau was -0.28 , indicating a weak negative correlation significant at the $p<0.05$ level for all irrigated catchments. 
Table 3. Correlation coefficients computed between normalized annual dissolved-solids loads and normalized annual monthly (April through October) average maximum temperature for selected catchments in the Upper Colorado River Basin.

[A p-value less than 0.05 represents a statistically significant correlation. na, not applicable; $<$, less than]

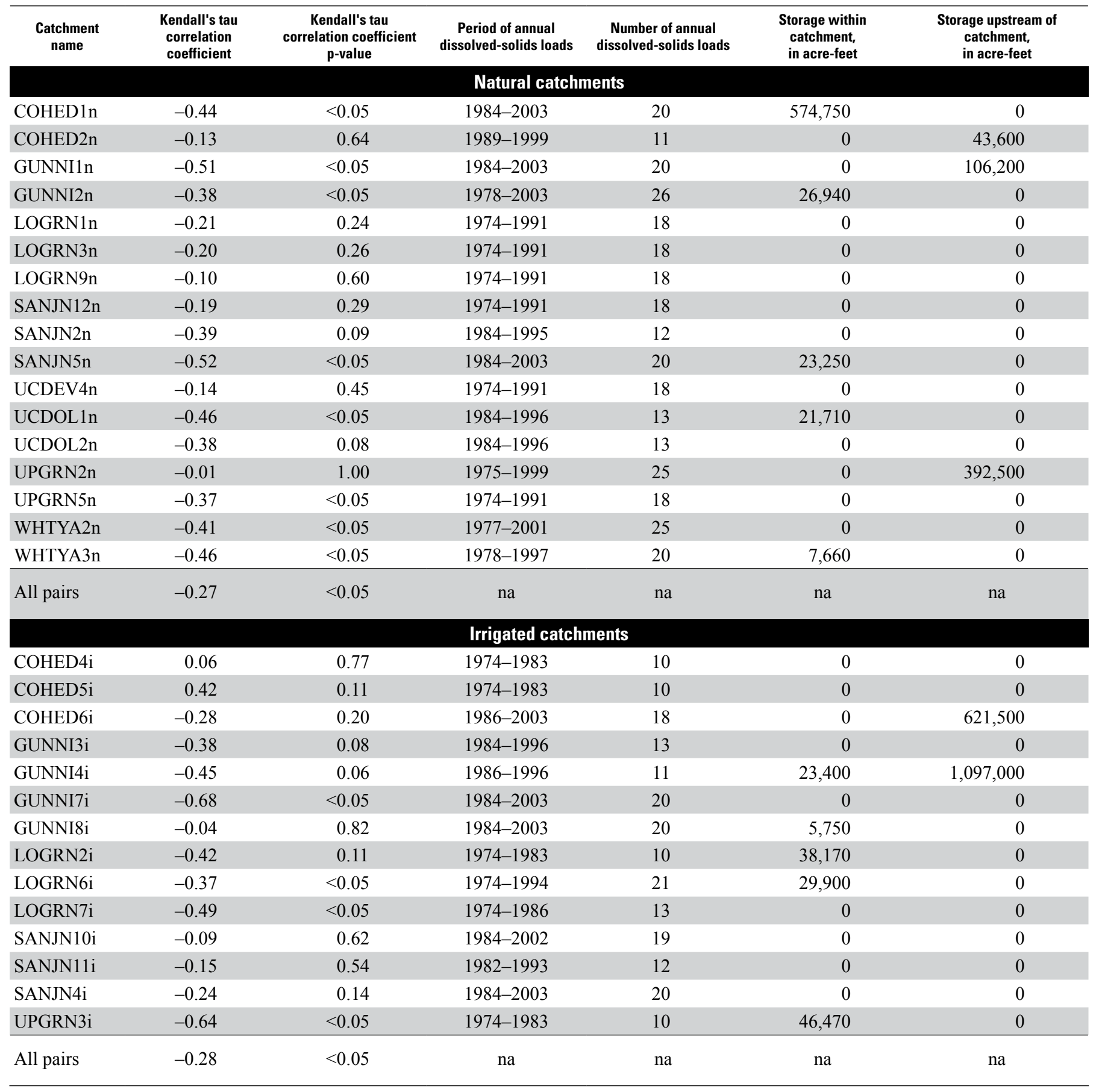




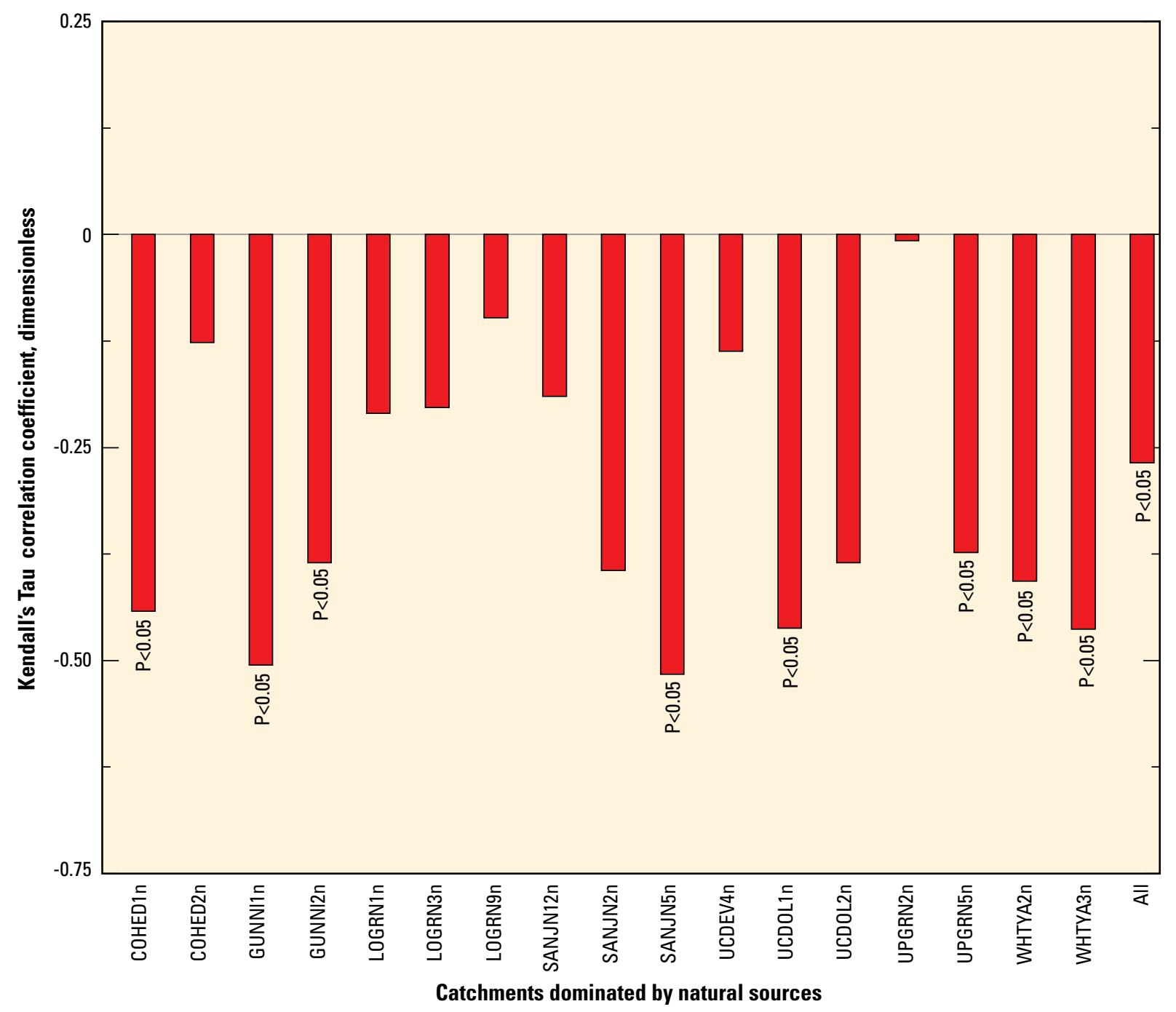

Figure 9. Correlation coefficients computed between normalized annual dissolved-solids loads and normalized annual monthly (April through October) average maximum temperature for natural catchments in the Upper Colorado River Basin. A p-value less than 0.05 represents a statistically significant correlation. 


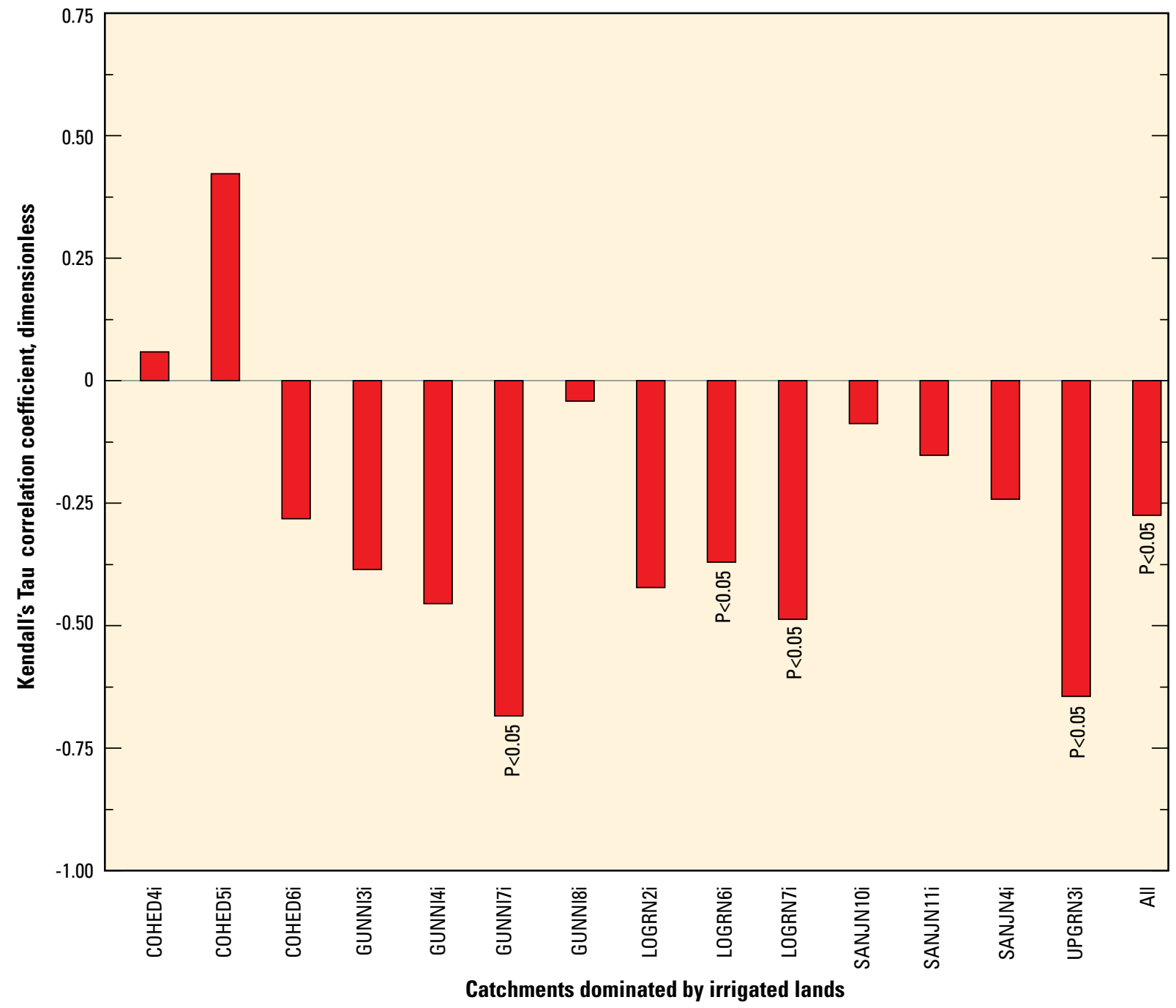

Figure 10. Correlation coefficients computed between normalized annual dissolved solids-loads and normalized annual monthly (April through October) average maximum temperature for irrigated catchments in the Upper Colorado River Basin. A p-value less than 0.05 represents a statistically significant correlation. 


\section{Response to Wet and Dry Periods}

Precipitation in the UCRB varies year-to-year in response to fluctuations in global climate patterns. Ocean temperature patterns, such as the El Niño-Southern Oscillation (ENSO) and the Pacific Decadal Oscillation (PDO) can be associated with periods of above- and below-average precipitation and streamflow in the Colorado River (Hidalgo, 2004; U.S. Geological Survey, 2004). The precipitation record for the UCRB from 1974 through 2003 shows a period of aboveaverage precipitation from 1982 through 1986, and a period of below-average precipitation from 2000 through 2003 (fig. 8). The highest 3-year average streamflow volume at Lees Ferry, Arizona since 1895, occurred from 1983 through 1985, and the lowest 3-year average occurred from 2000 through 2002 (U.S. Geological Survey, 2004). Dissolved-solids loading in the UCRB is most often evaluated annually (by water years) without consideration for the antecedent conditions in the basin. The effects of consecutive above- or below- average precipitation years on dissolved-solids loading in the basin have not been studied. Understanding differences in loading from irrigated and natural lands in response to wet or dry periods is of particular interest to this investigation.

\section{Antecedent Precipitation}

Antecedent precipitation conditions likely play a role in the delivery of dissolved solids to streams in the UCRB in subsequent years. For example, an above-average precipitation year can flush accumulated salts from the landscape, thereby reducing available salts for subsequent above-average precipitation years. In this example, if the above-average years were equal in precipitation, loads associated with the first year are likely to be greater. Above-average precipitation years often result in a rise in water tables as well. Both natural and irrigated basins with shallow groundwater tables or short groundwater flow paths can have continued or lagged dissolved-solids loading to streams in a subsequent average or below-average precipitation year.

\section{Dissolved-Solids Load Response to Wet Period}

In the UCRB, water years 1982 through 1987 defined one of the wetter periods in the precipitation record (fig. 8). Similarly, in most cases, the largest annual dissolved-solids loads for the study period were measured at monitoring stations throughout the basin during these years. The maximum normalized annual dissolved-solids load associated with this wet period for each of the catchments, along with the corresponding year, is shown in table 4 . The available periods of record for 1974 through 2003 for the catchments differed (table 4). Therefore, annual dissolved-solids loads data did not cover the entire wet period for some catchments but began in the middle or terminated before the end of the period. Natural catchments had a larger average annual maximum normalized dissolved-solids load during the wet period (1.85) than irrigated catchments (1.63). Natural catchments with in-catchment reservoir storage had a smaller average annual maximum normalized dissolved-solids load than natural catchments without storage, whereas the opposite was the case for irrigated catchments. Irrigated catchments with in-catchment storage had the largest average annual maximum normalized dissolved-solids load (2.05) of all catchment types examined.

From the limited dataset available for the wet period from 1982 through 1987, the year with the largest normalized dissolved-solids load appeared earlier in natural catchments than in irrigated catchments. The maximum normalized dissolvedsolids load for natural catchments with storage occurred, on average, 0.8 year before that in irrigated catchments with storage, and natural catchments without storage responded 0.7 year earlier than irrigated catchments without storage. Further, in-catchment storage in both natural and irrigated catchments is associated with an average response lag of 0.7 and 0.8 year, respectively.

\section{Dissolved-Solids Load Response to Dry Period}

A dry period from about 2000 through 2003 is evident in the precipitation record for the UCRB (fig. 8). Unfortunately, annual loads are only available for this entire dry period for 9 of the 31 study catchments. With data from such a small number of catchments, a comparable analysis to that of the dissolved-solids load response to a wet period presented in the previous section cannot be made here. Of the nine catchments that have data spanning this period, five are irrigated and four are natural. For the irrigated catchments, the average minimum annual dissolved-solids load was 0.61 . For the natural catchments, the average was 0.47 . As was the case in the dissolvedsolids load response to a wet period, the irrigated catchments generally showed a response similar to the natural catchments but of lower magnitude. Minimum normalized loads in irrigated catchments were greater than those for the natural catchments. There was only one irrigated catchment with in-catchment storage and only one natural catchment without in-catchment storage. Consequently, an examination of the annual dissolved-solids loads for catchments with and without in-catchment storage was not done.

\section{Reservoir Storage and Water Availability}

Reservoirs and water availability add to the complexity of factors affecting dissolved-solids loading in natural and irrigated catchments. One of the main purposes for most reservoirs in the UCRB is agricultural irrigation. Reservoirs are used to store water during the high-flow, spring snowmelt runoff period to augment base flows during the dry, summer growing season. Many of these reservoirs have the capacity to augment flows into the next year, if needed. Agricultural areas fortunate enough to have upstream storage generally have a similar amount of water available for irrigation in 
Table 4. Maximum normalized dissolved-solids loads during the wet period from 1982 through 1987 for selected catchments in the Upper Colorado River Basin.

[na, not applicable]

\begin{tabular}{|c|c|c|c|c|c|c|}
\hline Catchment name & $\begin{array}{l}\text { Catchment outlet } \\
\text { monitoring site } \\
\text { number }\end{array}$ & $\begin{array}{c}\text { Period of annual } \\
\text { dissolved-solids loads }\end{array}$ & $\begin{array}{c}\text { Storage within } \\
\text { catchment, } \\
\text { in acre-feet }\end{array}$ & $\begin{array}{l}\text { Storage upstream of } \\
\text { catchment, } \\
\text { in acre-feet }\end{array}$ & $\begin{array}{l}\text { Maximum normalized } \\
\text { dissolved-solids load } \\
\text { during period 1982-1987 }\end{array}$ & $\begin{array}{l}\text { Year of maximum normalized } \\
\text { dissolved-solids load during } \\
\text { period 1982-1987 }\end{array}$ \\
\hline \multicolumn{7}{|c|}{ Natural catchments } \\
\hline COHED2n & 09070000 & 1989-1999 & 0 & 43,600 & na & na \\
\hline GUNNI1n & 09110000 & 1984-2003 & 0 & 106,200 & 1.69 & 1984 \\
\hline LOGRN3n & 09279100 & 1974-1991 & 0 & 0 & 1.32 & 1986 \\
\hline LOGRN9n & 9326500 & 1975-1992 & 0 & 0 & 1.93 & 1985 \\
\hline SANJN12n & 09378630 & 1974-1991 & 0 & 0 & 3.15 & 1983 \\
\hline SANJN2n & 09346000 & 1984-1995 & 0 & 0 & 1.54 & 1985 \\
\hline UPGRN2n & 09217000 & 1982-1999 & 0 & 392,500 & 1.55 & 1983 \\
\hline UPGRN5n & 9235600 & 1974-1991 & 0 & 0 & 3.09 & 1983 \\
\hline WHTYA2n & 09303000 & $1977-2001$ & 0 & 0 & 1.34 & 1985 \\
\hline WHTYA3n & 09304200 & 1978-1997 & 7,660 & 0 & 2.06 & 1984 \\
\hline \multicolumn{5}{|l|}{ Average } & 1.85 & 1984.5 \\
\hline \multicolumn{5}{|c|}{ Average for catchments with in-catchment storage } & 1.76 & 1985.0 \\
\hline \multicolumn{5}{|c|}{ Average for catchments without in-catchment storage } & 1.89 & 1984.3 \\
\hline \multicolumn{7}{|c|}{ Irrigated catchments } \\
\hline GUNNI8i & 09152500 & $1984-2003$ & 5,750 & 0 & 1.22 & 1994 \\
\hline LOGRN2i & 09271500 & $1974-1983$ & 38,170 & 0 & 2.76 & 1983 \\
\hline LOGRN6i & 09302000 & 1974-1994 & 29,900 & 0 & 1.97 & 1983 \\
\hline LOGRN7i & 09314280 & $1974-1986$ & 0 & 0 & 1.41 & 1983 \\
\hline SANJN10i & 09371010 & 1984-2002 & 0 & 0 & 1.55 & 1985 \\
\hline SANJN11i & 09371500 & $1982-1993$ & 0 & 0 & 1.32 & 1993 \\
\hline SANJN4i & 09355000 & $1984-2003$ & 0 & 0 & 1.45 & 1987 \\
\hline UPGRN3i & 09222000 & $1974-1983$ & 46,470 & 0 & 2.59 & 1983 \\
\hline \multicolumn{5}{|l|}{ Average } & 1.63 & 1985.3 \\
\hline \multicolumn{5}{|c|}{ Average for catchments with in-catchment storage } & 2.05 & 1985.8 \\
\hline \multicolumn{5}{|c|}{ Average for catchments without in-catchment storage } & 1.36 & 1985.0 \\
\hline
\end{tabular}


most years. This would indicate that dissolved-solids loads from irrigated lands with upstream storage are not likely to decrease during short periods of below-average precipitation because, in general, the same amount of water is available and applied to the land. However, under a persistent dry period, such as one lasting more than a couple of years, the availability of this water source can decline because of finite storage capacity and preferential water rights. In this case, less water is applied to agricultural lands, which, intuitively, should lead to smaller dissolved-solids loads. Further, loads associated with agricultural lands having shallow groundwater systems are likely to be larger during periods of elevated water tables. Assuming that a similar amount of water is applied to crops, given its continued availability, more water is likely to be discharged from these lands to streams as both irrigation return flow and groundwater discharge. Irrigated catchments with in-catchment storage had the largest average annual maximum dissolved-solids loads during the wet period from 1982 through 1987, compared with any other catchment type studied. The reason for the increased variability and large annual maximum loads for irrigated catchments with reservoir storage is not clear, but one reason for this could be related to the constant supply of water provided by reservoirs which in turn, allows for about the same amount of water to be applied to crops each year. With high water tables, the application of the same amount of water as would be applied in a dry year could generate an exceptional amount of load. On average, the annual loads associated with irrigated catchments with in-catchment storage showed the greatest positive skew of the studied catchment types (appendix 1). This could indicate that the largest loads, likely from wet years, associated with irrigated catchments with storage could be amplified as a result of irrigation practices. Natural catchments with and without reservoir storage showed similar variability to one another (table 1). The reservoirs in the natural catchments did not appear to create much of a lag in dissolved-solids transport over an annual time frame.

\section{Limitations}

The analyses presented in this report have limitations that must be considered when interpreting the results. The 31 selected catchments used throughout this analysis fall short of adequately representing the variety of catchments in the UCRB. The periods of record for the selected catchments generally do not span the entire 1974 through 2003 period of study. The periods of record vary from one catchment to another, and the selection criteria were set at a minimum of 10 consecutive years of annual dissolved-solids loads. The average period of record was 16.6 years. On the basis of the results presented in Kenney and others (2009), a criterion for the natural catchments was that no more than 10 percent of the dissolved-solids load was attributed to irrigated lands. Similarly, a criterion for the irrigated catchments was that at least 70 percent of the dissolved-solids load was attributed to irrigated lands. Using these criteria, for each catchment type, there is some portion of the load associated with the other, less desirable, dissolved-solids source. Further, in the irrigated catchments, the amount of irrigated land makes up only a small portion of the defined catchment area (appendix 1), even though at least 70 percent of the load was attributed to irrigated lands. The sample size used in this study (31 catchments, with 14 irrigated agricultural catchments and 17 natural catchments) is a small population for a robust analysis. With such a small sample size, the ability to draw conclusions applicable throughout the UCRB is limited.

There is uncertainty in the computed dissolved-solids loads at the monitoring stations, related to various sources of measurement error (Kenney and others, 2009). Dissolvedsolids loads are derived from analyses of dissolved-solids concentrations, specific-conductance measurements, daily mean streamflow computations, and statistical modeling. These data were measured and analyzed by USGS personnel in accordance with USGS standards and techniques as outlined in Rantz and others (1982), U.S. Geological Survey (variously dated), and Fishman and Friedman (1989). By using the measurements and lab analyses obtained at the monitoring stations, annual loads were computed by using statistical load models as described in Anning and others (2007). The amount of uncertainty associated with measurement error is difficult to quantify; however, because standard procedures were followed for the measurements and lab analyses, measurement errors were assumed to be generally equivalent for each site.

This analysis of catchment types is based on subtracting an upstream dissolved-solids load from the load computed at the catchment outlet monitoring station. Loads from upstream monitoring stations can be orders of magnitude less than the loads at the catchment outlet monitoring station, or these upstream loads can make up a large percentage of the outlet station loads. The uncertainties, or range of likely values, as well as the rounding precision of computed loads, were not considered when these calculations were made. These issues are particularly important when evaluating the results associated with the catchments located on the main stems of the larger rivers, such as the Green, San Juan, and Colorado Rivers.

It is well-known that irrigation practices, specifically sprinkler irrigation and flood irrigation, have an effect on dissolved-solids loading. Sprinkler irrigation is more efficient than flood irrigation in terms of the amount of water applied and consumed. Mitigation of dissolved-solids loading from irrigated lands often consists of replacing flood-irrigation infrastructure with sprinklers. It is likely that in some catchments, both irrigation practices existed, and it is conceivable that irrigation practices on many irrigated lands changed from flood to sprinkler during the period of study. For this analysis, however, no distinction among irrigation practices on irrigated lands was made and all irrigated lands were treated the same.

Physical processes related to dissolved-solids loading in streams of the UCRB generally are less complicated when 
viewed on a regional scale. This analysis was conducted at a very local scale, where processes can be very complex, including such things as local groundwater-surface-water interactions, small-scale water development, and other human activities and behaviors, such as crop irrigation. While the annual time scale mitigates some of these issues, local processes can affect the annual loading of dissolved solids differently in each catchment. When considering local processes, it is important to understand that dissolved-solids yield (the amount of load per area) in a given basin is not static in time. Trends in dissolved-solids concentrations related either to salinity control projects or natural processes have been identified during the period of study (Liebermann and others, 1989; Chafin, 2002; Anning and others, 2007; Leib and Bauch, 2008).

The results presented in this report are specific to the period of study and the catchments included in this analysis. At this point, the conclusions drawn are not meant to apply to the entire UCRB; rather, they should be used to guide further investigation and monitoring of salinity loading from irrigated and natural catchments. In general, more data are needed to accurately distinguish loading characteristics for irrigated and natural basins, both with and without in-catchment storage.

\section{Summary}

Dissolved-solids loads in natural and irrigated catchments generally increased and decreased concurrently during the period of study from 1974 through 2003 in the Upper Colorado River Basin (UCRB). The average magnitude of these changes, computed from the average annual dissolved-solids load, from one year to the next, indicated that the magnitude of change in dissolved-solids loads in natural catchments was about 10 percent greater than in irrigated catchments. Statistical measurements of variability, or spread, computed using the time series of dissolved-solids loads for each catchment, indicated that the average variability of the natural catchments was about 35 percent greater than the variability of the irrigated catchments.

Dissolved-solids loads from natural catchments were positively correlated to precipitation. Significant positive correlations were found in 15 of the 17 natural catchments examined, whereas, 7 of the 14 irrigated catchments had a significant positive correlation. Using all pairs of available dissolved-solids load and precipitation data, a positive correlation between them was determined for natural catchments, and a weak positive correlation was found between them in irrigated catchments. These results indicated that precipitation was related to dissolved-solids loading from natural catchments more strongly than from irrigated catchments. The correlation between temperature and dissolved-solids loads in this study was generally negative. Kendall's rank correlation test indicated that 8 of the 17 natural catchments had a significant negative correlation, and 7 of the 14 irrigated catchments had a significant negative correlation. Using all pairs of available dissolved-solids loads and temperature, weak negative correlations were determined for both irrigated and natural catchments.

The years from 1982 through 1987 define one of the wettest periods in the UCRB. On the basis of the maximum normalized annual dissolved-solids load associated with these years, the response of loading to the above-average precipitation in irrigated catchments generally lagged behind the response in natural catchments, and normalized annual loads generally were smaller than in natural catchments. On average, however, irrigated catchments with in-catchment reservoir storage had the largest normalized maximum annual loads.

\section{References Cited}

Anning, D.W., Bauch, N.J., Gerner, S.J., Flynn, M.E., Hamlin, S.N., Moore, S.J., Schaefer, D.H., Anderholm, S.K., and Spangler L.E., 2007, Dissolved solids in basin-fill aquifers and major river systems in the southwestern United States: U.S. Geological Survey Scientific Investigations Report 2006-5315, 168 p.

Chafin, D.T., 2002, Effect of the Paradox Valley unit on the dissolved-solids load to the Dolores River near Bedrock, Colorado, 1988-2001: U.S. Geological Survey WaterResources Investigations Report 02-4275, 6 p.

Fishman, M.J., and Friedman, L.C., 1989, Methods for determination of inorganic substances in water and fluvial sediments: U.S. Geological Survey Techniques of WaterResources Investigations, book 5, chap. A1, 545 p.

Helsel, D.R., and Hirsch, R.M., 1992, Studies in environmental science 49: Statistical methods in water resources: Amsterdam, The Netherlands, Elsevier Science Publishers, $491 \mathrm{p}$.

Hidalgo, H.G., 2004, Climate precursors of multidecadal drought variability in the western United States: Water Resources Research, v. 40, 10 p.

Iorns, W.V., Hembree, C.H., and Oakland, G.L., 1965, Water resources of the Upper Colorado River Basin-technical report: U.S. Geological Survey Professional Paper 441, $370 \mathrm{p}$.

Kenney, Terry A. and Susan G. Buto, 2012, Evaluation of the temporal transferability of a model describing dissolved solids in streams of the Upper Colorado River Basin. Journal of the American Water Resources Association (JAWRA) p. 13. DOI: $10.1111 /$ j.1752-1688.2012.00667.x 
Kenney, T.A., Gerner, S.J., Buto, S.G., and Spangler, L.E., 2009, Spatially referenced statistical assessment of dissolved-solids load sources and transport in streams of the Upper Colorado River Basin: U.S. Geological Survey Scientific Investigations Report 2009-5007, 50 p., available online at http://pubs.usgs.gov/sir/2009/5007.

Leib, K.J., and Bauch, N.J., 2008, Salinity trends in the upper Colorado River Basin upstream from the Grand Valley Salinity Control Unit, Colorado, 1986-2003: U.S. Geological Survey Scientific Investigations Report 2007-5288, 21 p.

Liebermann, T.D., Mueller, D.K., Kircher, J.E., and Choquette, A.F., 1989, Characteristics and trends of streamflow and dissolved solids in the Upper Colorado River Basin, Arizona, Colorado, New Mexico, Utah, and Wyoming: U.S. Geological Survey Water-Supply Paper 2358, 64 p.

PRISM Group, 2007, Digital climate data: Oregon State University, accessed August 2009 at http://www.ocs. oregonstate.edu/prism/index.phtml.
Rantz, S.E., and others, 1982, Measurement and computation of streamflow-Volume 1. Measurement of stage and discharge, and Volume 2. Computation of discharge: U.S. Geological Survey Water-Supply Paper 2175, 631 p.

U.S. Department of the Interior, 2009, Quality of water-Colorado River Basin progress report no. 23, 75 p., accessed March 9, 2011 at http://www.usbr.gov/uc/progact/salinity/ $p d f s / P R 23 . p d f$

U.S. Geological Survey, variously dated, National field manual for the collection of water-quality data: U.S. Geological Survey Techniques of Water-Resources Investigations, book 9, chaps. A1-A9, available at http://pubs.water.usgs.gov/ twri9A

U.S. Geological Survey, 2004, Climatic fluctuations, drought, and flow in the Colorado River Basin: U.S. Geological Survey Fact Sheet 2004-3062, version 2, available at http:// pubs.usgs.gov/fs/2004/3062/ 


\section{Appendix 1.}

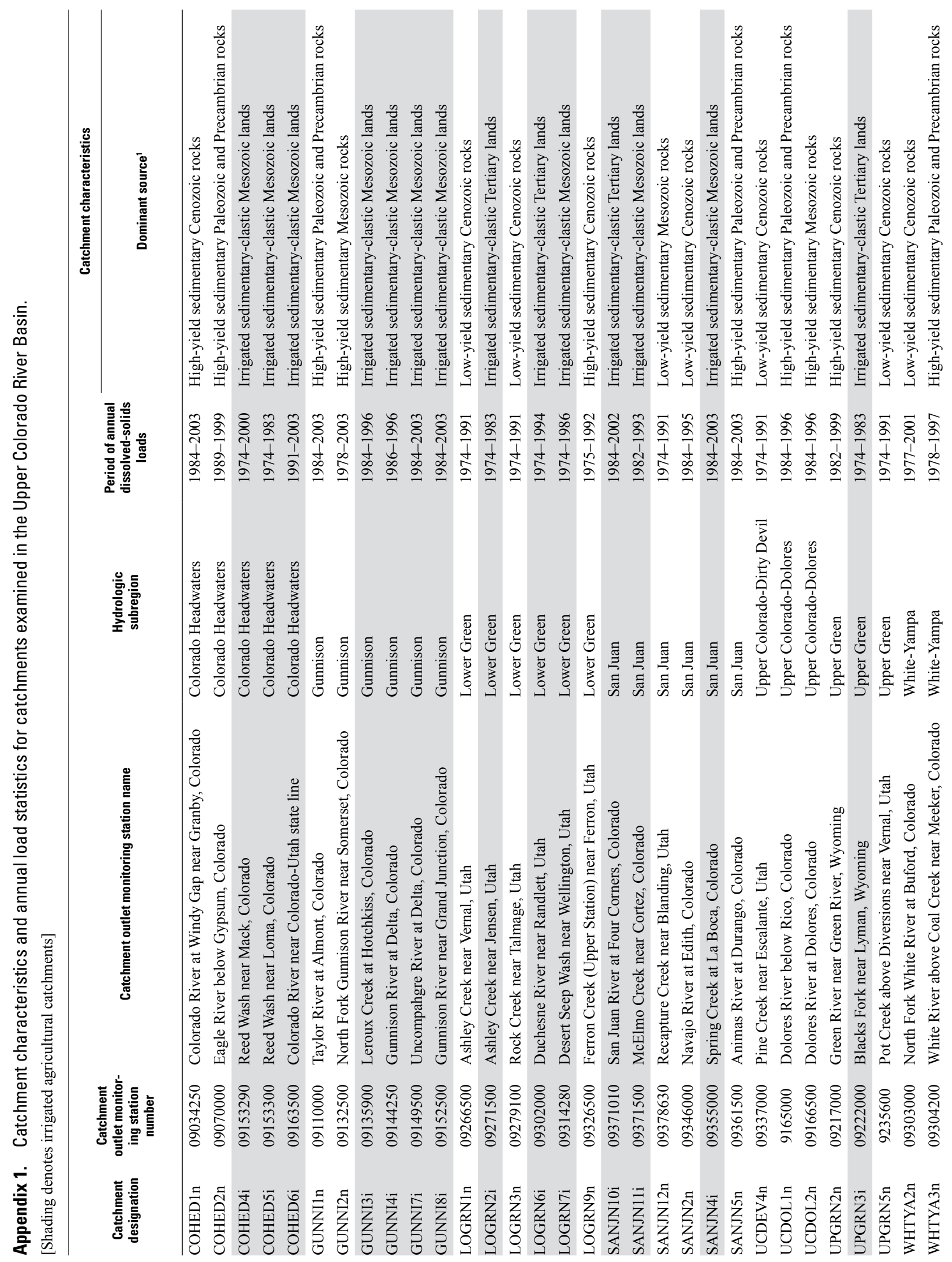




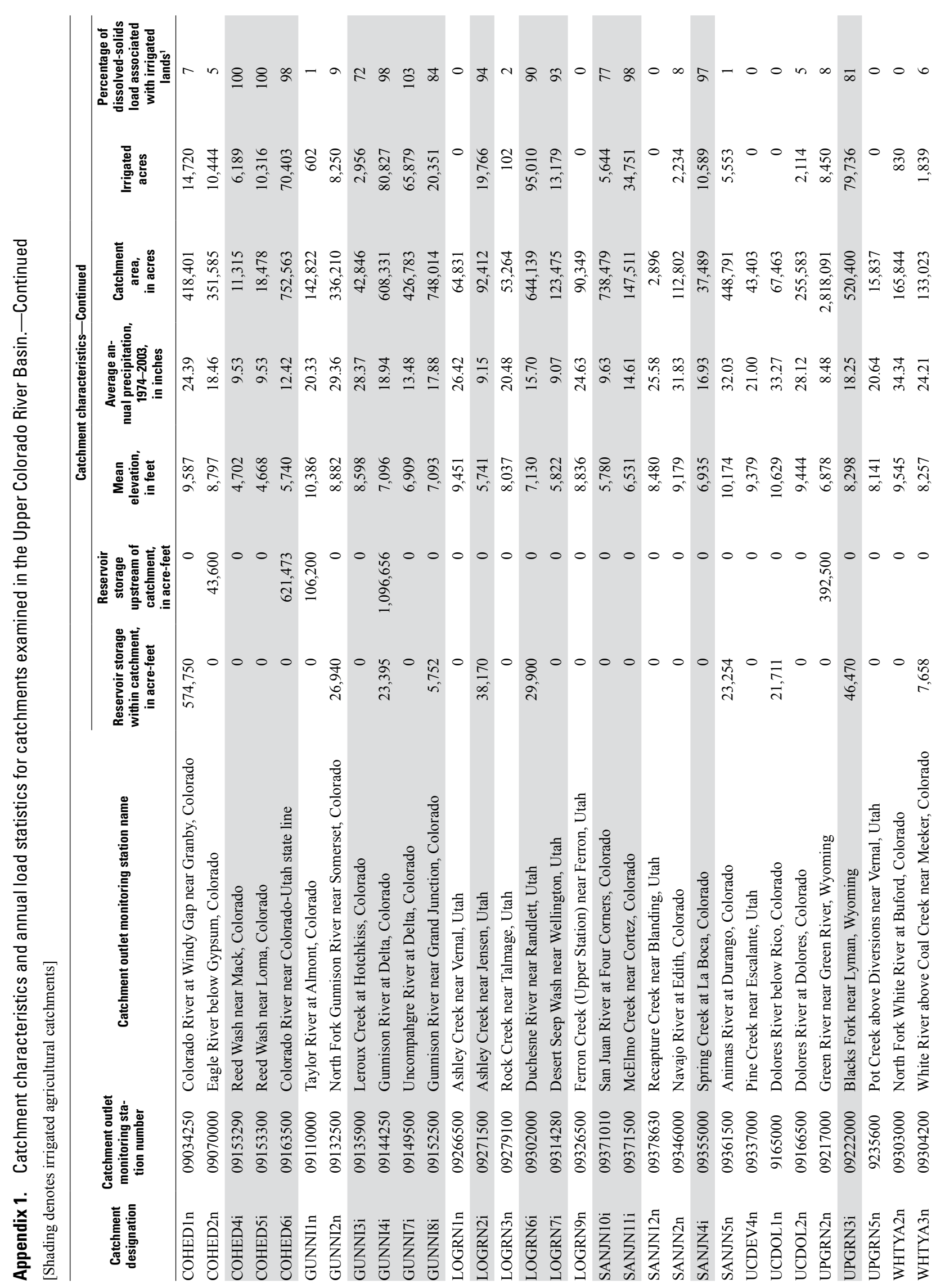




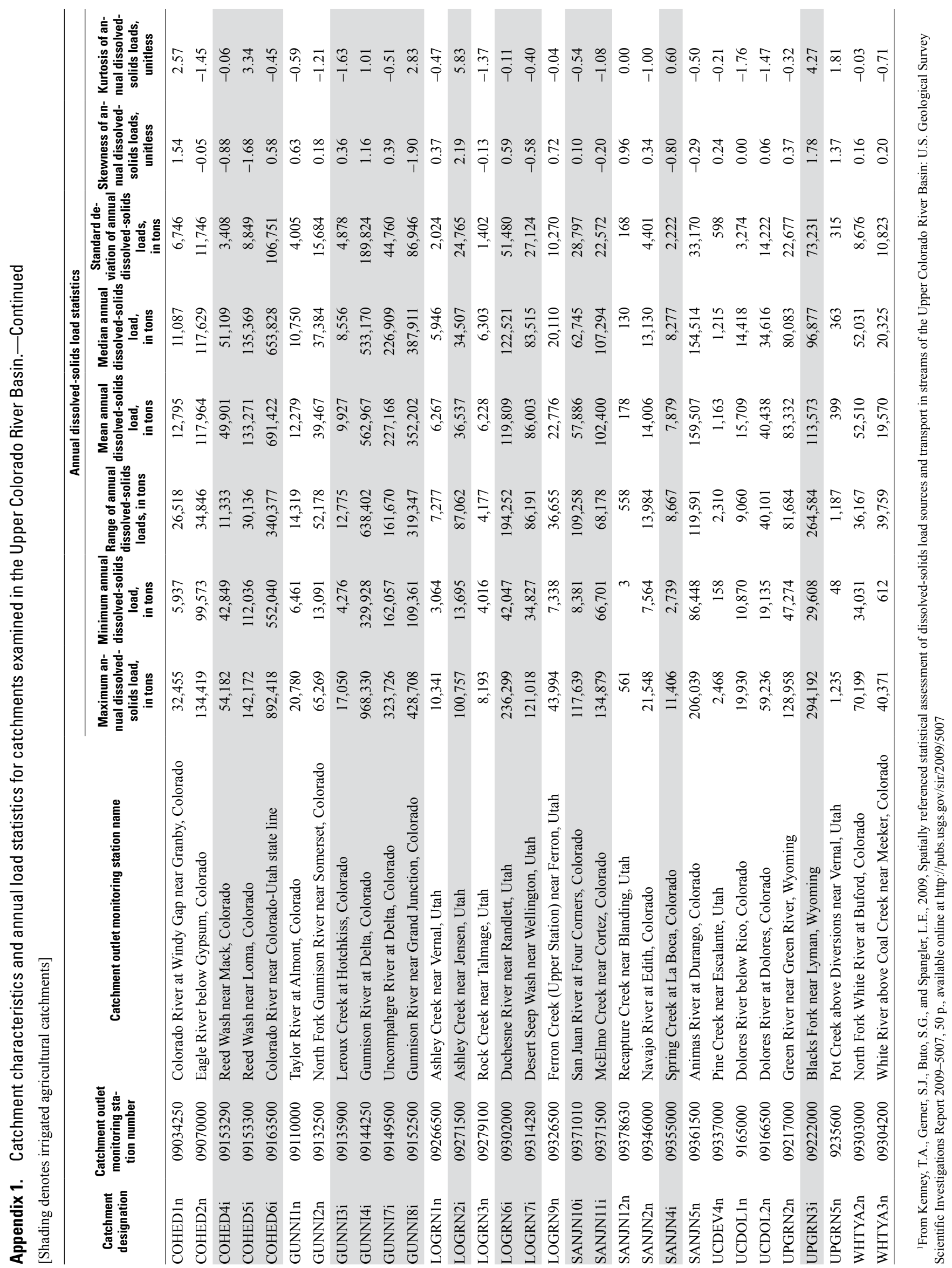




\section{Appendix 2.}

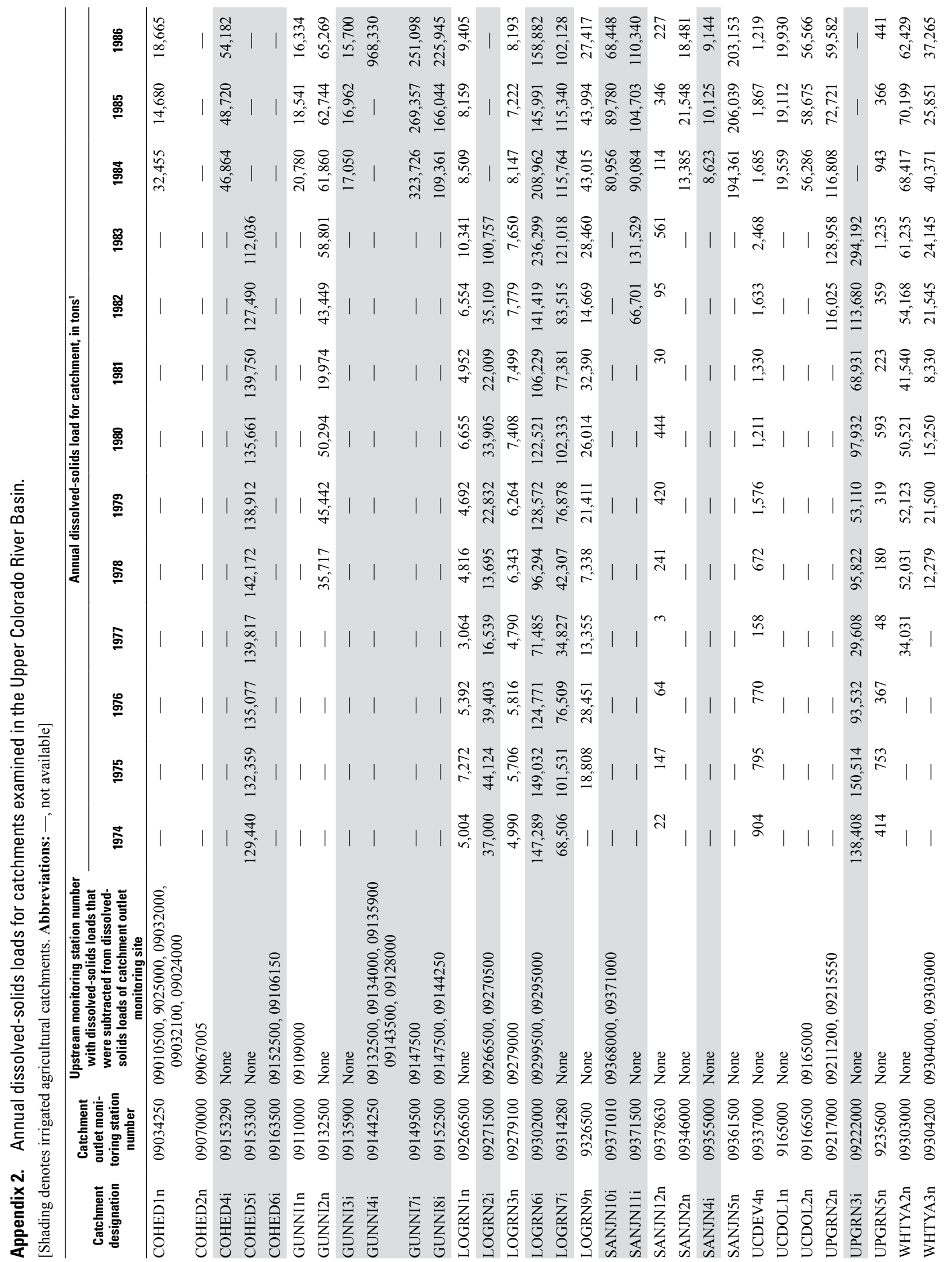




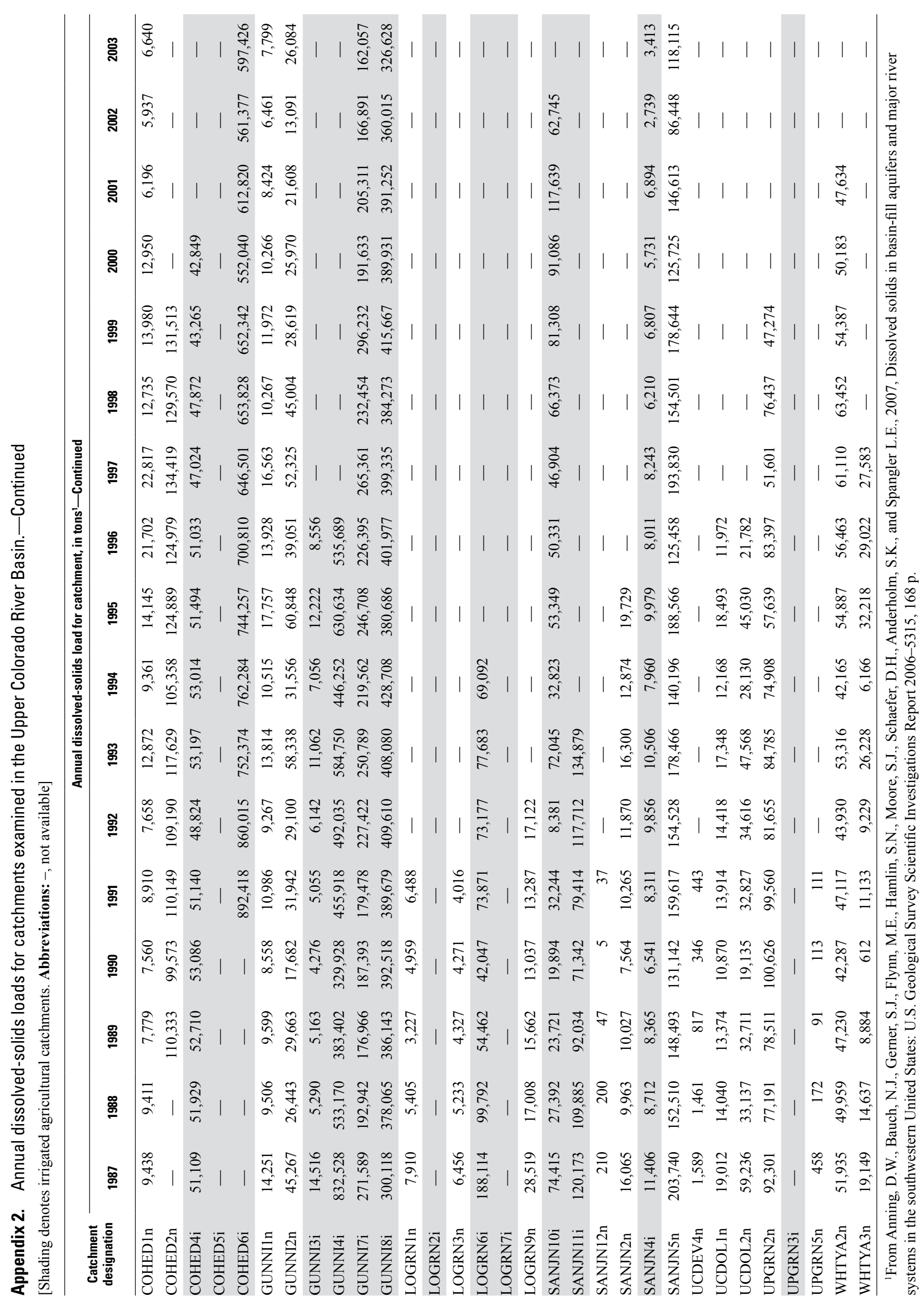




\section{Appendix 3.}

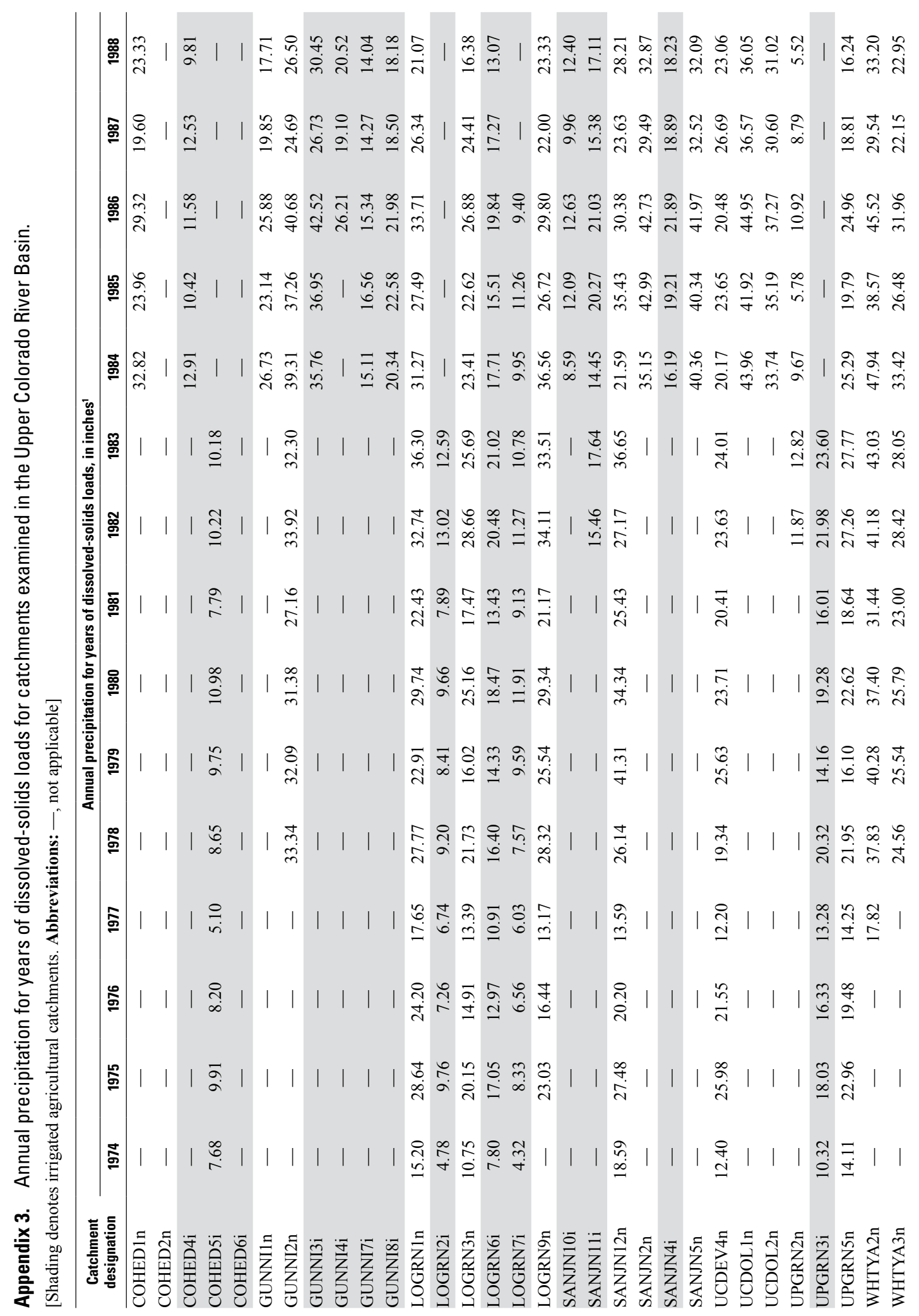




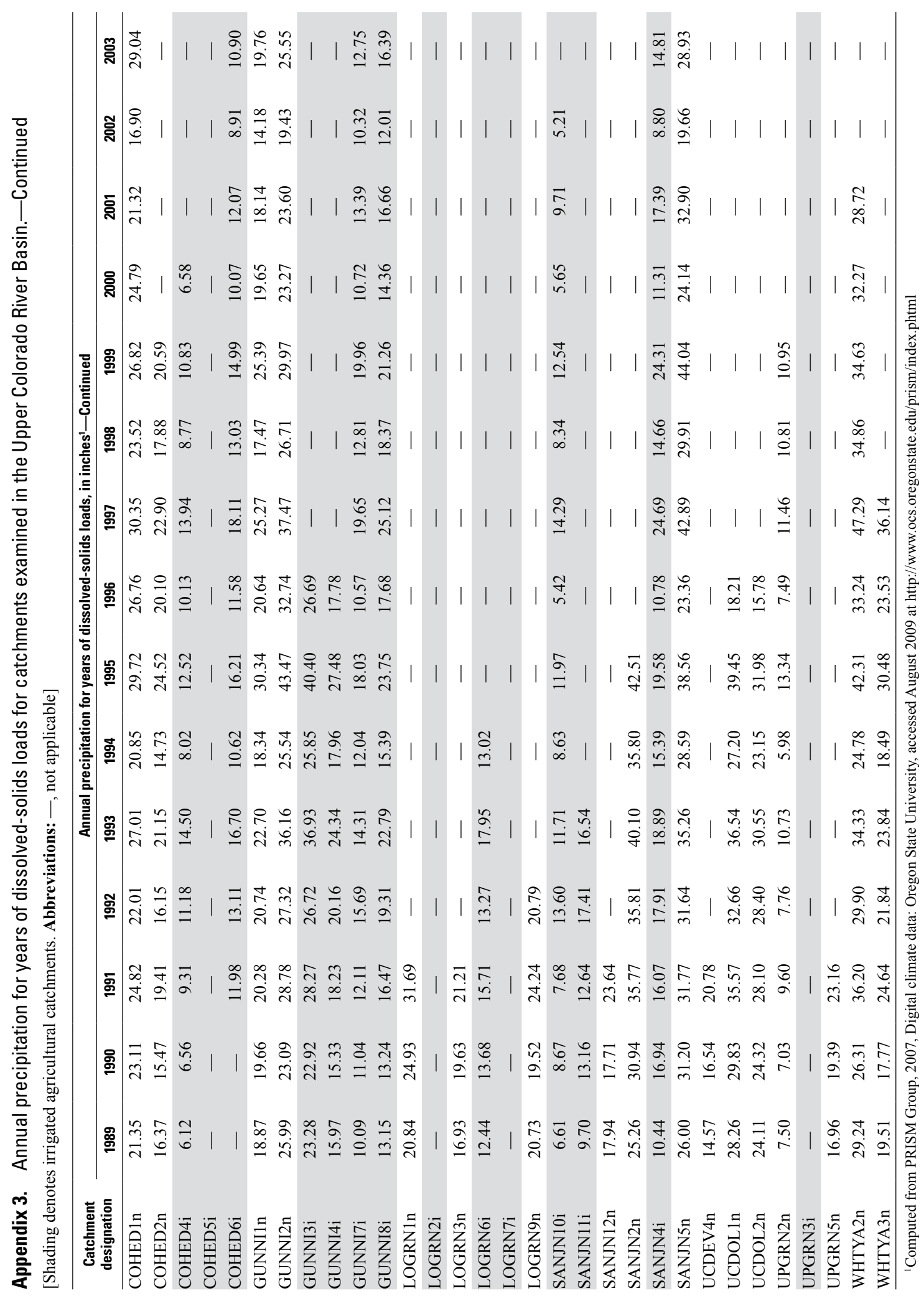




\section{Appendix 4.}

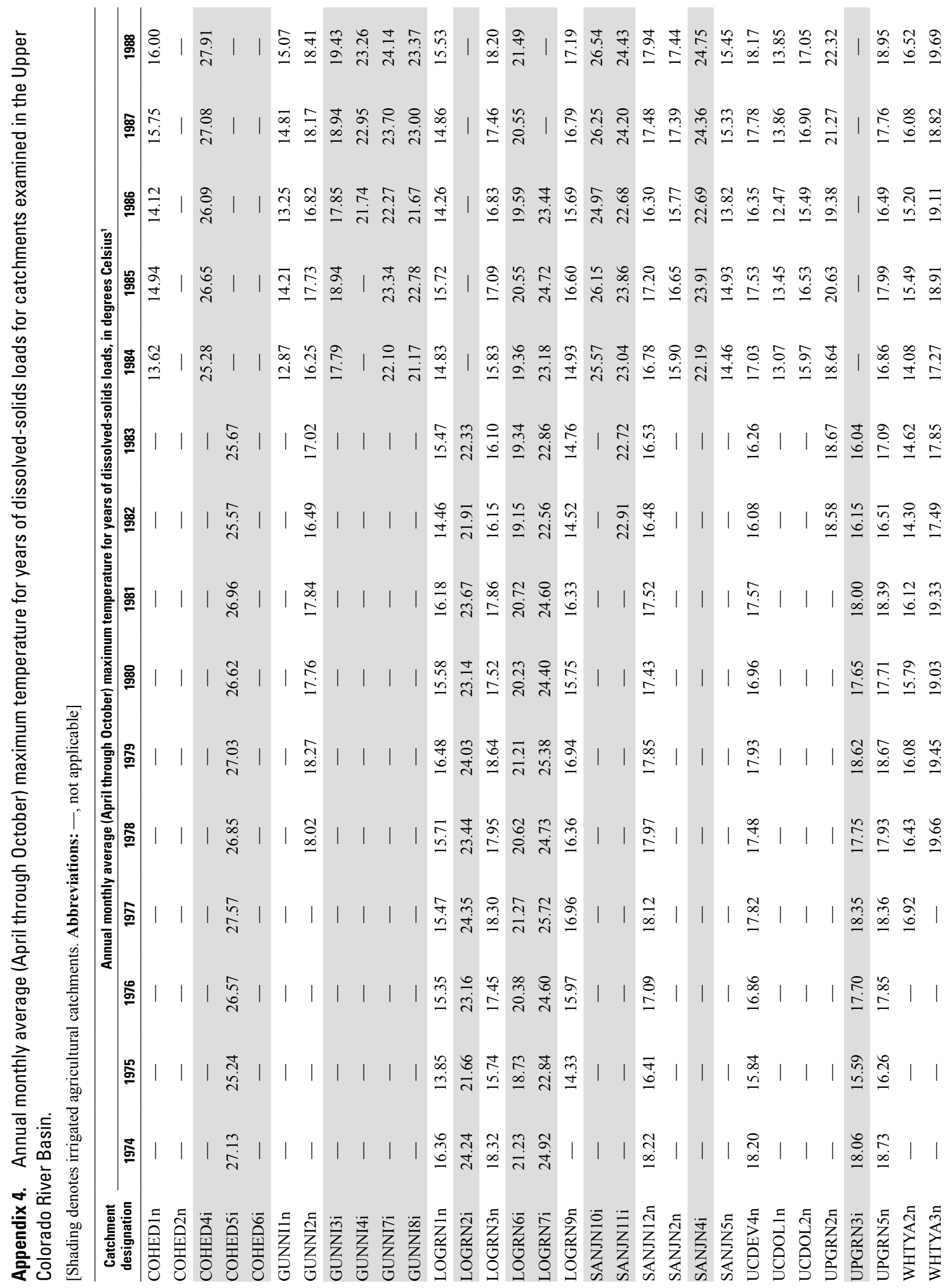




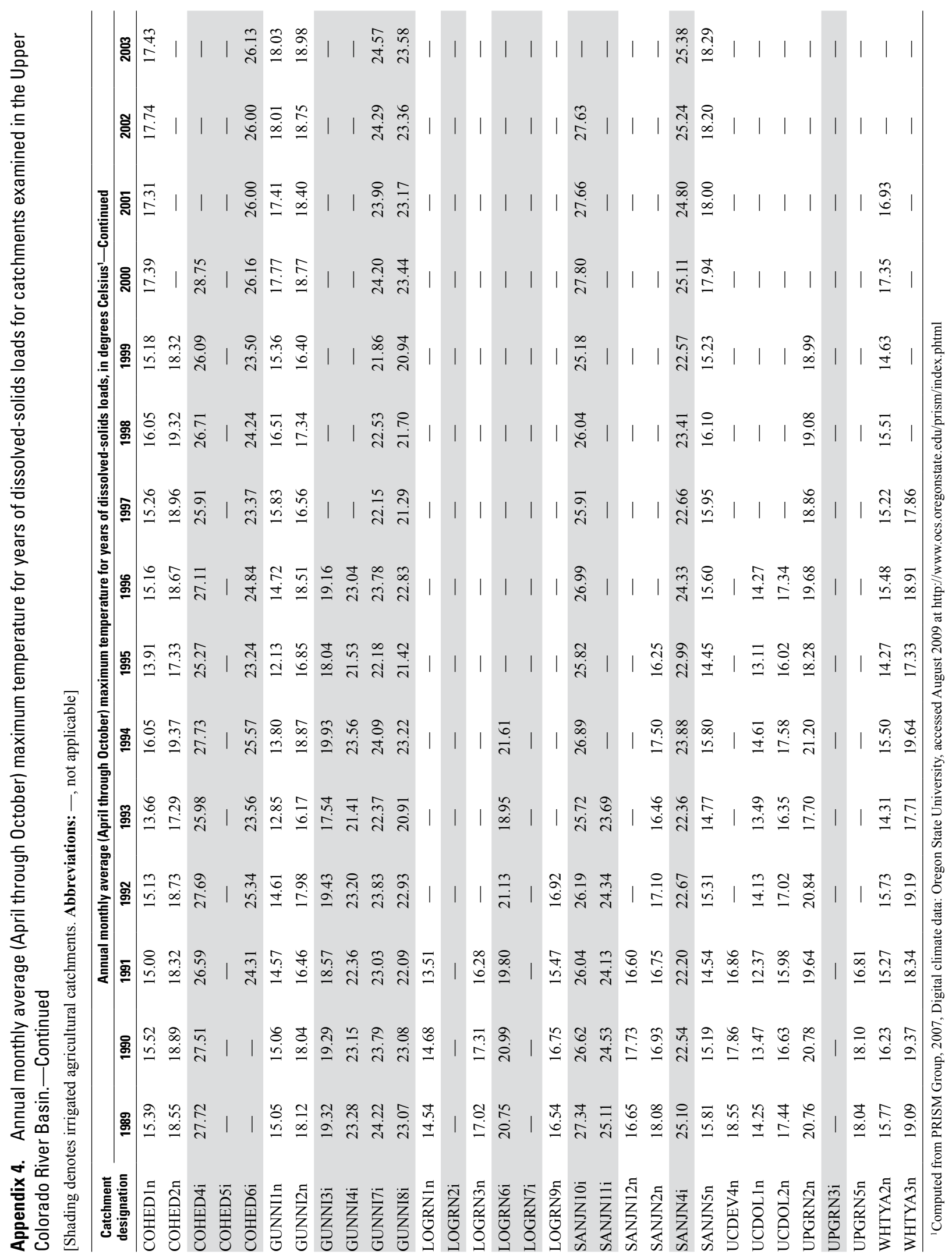





\section{$\frac{1}{8}$}

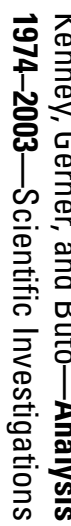

귱 음

울

등 흠

긍

당응

\}

¿্口

5

홓

을

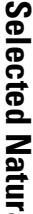

을

三.

홍

8

产

$\Xi$

등

8

웅

স্刃্র

品.

8 Printed on recycled paper 